Historic, Archive Document

Do not assume content reflects current scientific knowledge, policies, or practices. 

See Inside for Winners of 1927 Cabbage Plant Contest.
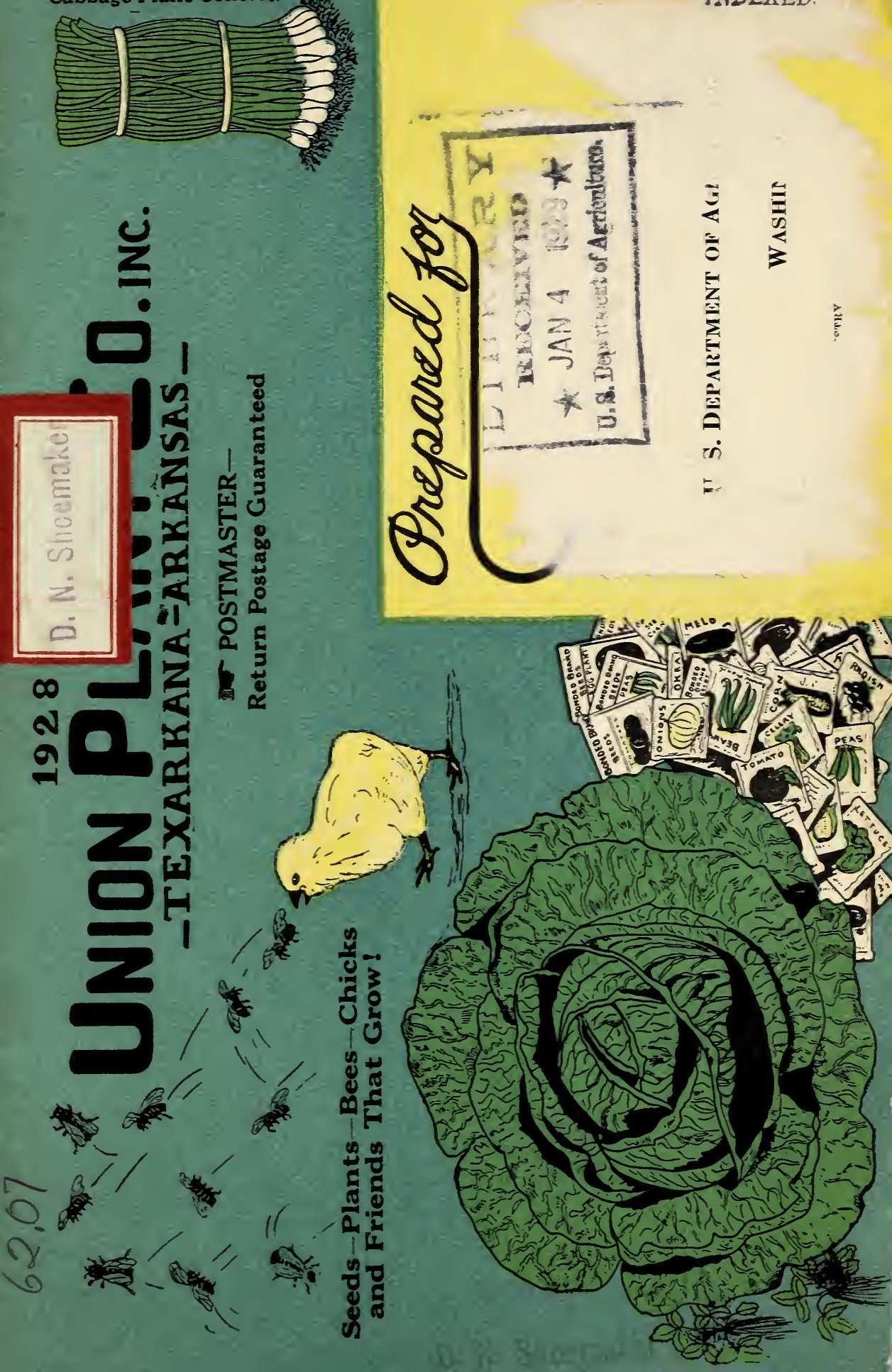

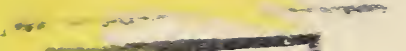$$
\text { त्र } * \text { 丵 }
$$

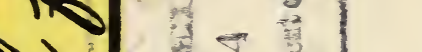$$
=3
$$

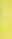

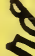$$
\text { (1) }
$$$$
\text { \% }
$$$$
\text { Cabbage Plant Contesto }
$$
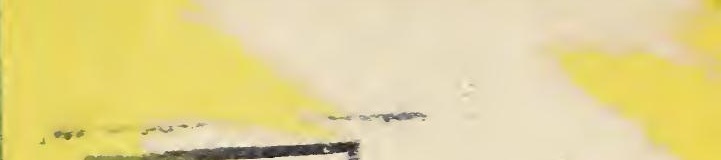


\section{Results of our Contest}

\section{on \\ Prizehead Cabbage Plants}

Last year, we announced a $\$ 500$ cash prize contest, whereby three prizes, amounting to $\$ 250, \$ 150$ and $\$ 100$, were to be awarded for the largest and best heads of cabbage grown from our Prizehead Cabbage Plants. 1500 people entered this contest, from 29 different states. 500 people sent entries, and what beautiful cabbage was grown!

The First prize was won by Peter Porter of Edinburg, Ill. Weight of Cabbage, $16 \frac{1}{2}$ pounds. Mr. Porter also won the Third prize with his 15 pound Cabbage. The Second prize was won by E. Buschmann, Pequot, Minn., the weight of his cabbage being 16 pounds.

\section{We wanted to Convince our Customers and Friends of the Merits of this Superior Cabbage}

The object of our Contest was to introduce our Prizehead Cabbage Plants. Instead of making a lot of idle claims about it, we thought we'd let our customers try it, in this way, and we'd wait a whole season to let them watch results. Those who did buy and try the Prizehead plants now KNOW their superiority. These plants make large and showy cabbages, conical round in shape, with short stem and it almost rests on the ground. Matures early and all together. FROSTPROOF!

\section{Prices of Prizehead Cabbage Plants}

Sent by Parcel Post-Prepaid: 100 plants, 60c; 200, $\$ 1.00 ; 300, \$ 1.25 ; 500$, \$2.00; 1,000, \$3.50; 5,000, $\$ 15.00$.

\section{Read what the winners and other contestantssay:}

\section{Aug. 15, 1927.}

"I am shipping two heads of Cabbage, grown from your Prizehead plants. I am loaded down with compliments from people who have seen $m y$ cabbages. The people from Springfield and other towns were amazed at seeing such marvelous heads of cabbage. They are large size, very crisp and most compact of any I have ever grown, in spite of a very unfavorable season.'

Peter Porter, Edinburg, III.

July $26,1927$.

"I bought 200 Prizehead plants and set out about middle of April and latter part of June we had cabbage to use. It's the finest cabbage we ever raised, both in quality and texture."

Elmer F. Rudisill, R.F.D. 1, Monticello, III. Aug. 22, 1927

"Prizehead is wonderful cabbage and just right for market. The merchants who have bought cabbage from me this sumner, invarlably ordered some more of it again.

A. J, Sluzalis, R.R. 5, Box 10, Canton, IIl.
Aug. 27, 1927.

"Am sending you one Prizehead Cabbage, weighing 16 pounds. We have some weighing heavier, but not as good as this in firmness and shape. My cabbages cleaned the County Fair slick and clean and took first prizes in all entries."

\section{E. Buschmann, Pequot, Minn.}

Aug. 24, 1927.

"I have been in the gardening business for nearly 50 years and I can safely say that your Prizehead Cabbage is the best I have ever seen or grown and believe $m e$, I have seen and handled quite a few in my 50 years in the business. THEY ARE EARLY-FINE GRAIN-AND VERY SWEET."

Caleb Marlow, Elgin, 11.

June 27. 1927.

"I can say for this Prizehead Cabbage, it makes larger heads and quicker than any other cabbage I have ever raised, beating others set at the same time."

Otto Craycroft, Sandoral, Ill.

Don't throw this catalog away-It would be like losing a friend! 


\section{HOWDY!}

Hello Folks-Here's a message of greeting to our old friends, and we hope many new friends. This catalog is a way in which we can talk to thousands and thousands of people, telling them about our fine plants, seeds, etc., and giving them a valuable reference book.

For many years we have sold Cabbage and Onion Plants. Our customers ordered year after year. Then they asked why they couldn't order other plants and seeds from us. They

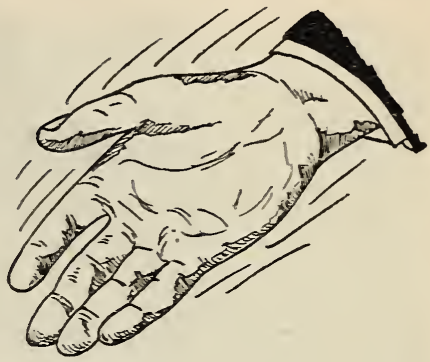
had confidence in us. So we have enlarged our line until we handle most all other plants, seeds, bees and baby chicks.

We want you to be satisfied always-if you're not, PLEASE write us!

\section{Let us meet as friends-or greet as old friends, Howdy!}

\section{N D E X}

A

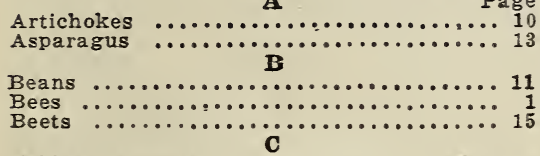

Cabbage Plants .................. 3, 4

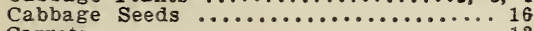

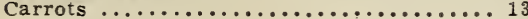

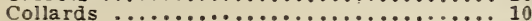

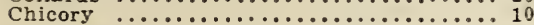

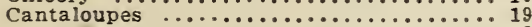

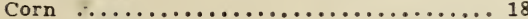

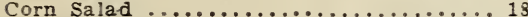

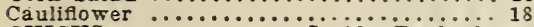

CHICKS................. Inside Back Cover

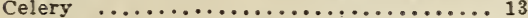

Cucumbers ....................... 12

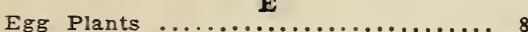

Egg Plant seeds..........................

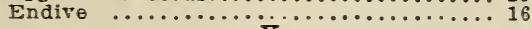

Kale $\ldots \ldots \ldots \ldots \ldots \ldots \ldots \ldots \ldots \ldots \ldots \ldots \ldots \ldots 14$

Kohl $\operatorname{Rabi}{ }^{\prime} \ldots \ldots \ldots \ldots \ldots \ldots \ldots \ldots \ldots \ldots \ldots \ldots \ldots \ldots \ldots 114$

Leek $\ldots \ldots \ldots \ldots \ldots \ldots \ldots \ldots \ldots \ldots 16$
$\mathbf{M r}$

o

Page

Okra

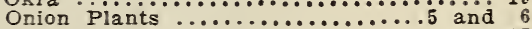

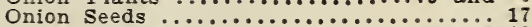

Order Blanks ............................ and 23

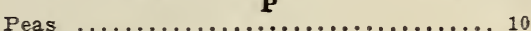

Pepper Plants ........................

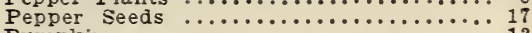

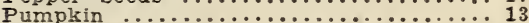

Prize Contest (1927).... Inside Front Cover $\mathbf{R}$

Radishes ..................... 17

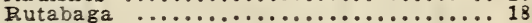

Salsify ........................ 16

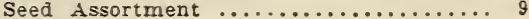

Special Offers.........4, 9 and $\ddot{\mathrm{Back}}$ Cover

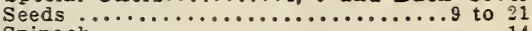

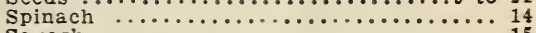

Squash $\ldots \ldots \ldots \ldots \ldots \ldots \ldots \ldots \ldots \ldots \ldots \ldots \ldots \ldots 15$

Strawberry Plants ................ 7

Tomato Plants ................... 8

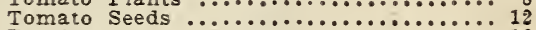

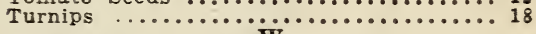

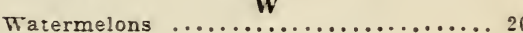

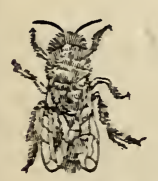

Let These Bees Make Honey and Money for You

Bees make a profitable sideline. They do the work for rou. Bees purchased in the spring should produce surplus honey the first year. Common black bees may be changed into Italians by introducing a pure bred Italian Queen. Improve your hive.

Two-pound package pure bred three-banded Italian Bees with queen. Queens selected for size and color. Bees guaranteed to be free of disease. We will replace any loss in transit, if express reeeipt bearing notation of damage is returned promptly. Complete directions for transferring.

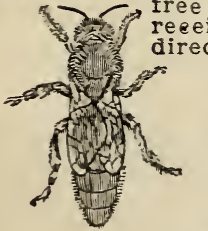

Two-pound package of Bees, with Queen. By express only. Shipping weight, 7 pounds.

...................... Three-pound package, with Queen. By express only. Shipping weight, 9 pounds...\$\$1.95
Pure bred, select Queen Bee only. Postpaid, each......98c Shipped from Louisiana or Texas.

Write us for special catalog of Bee Supplies. 


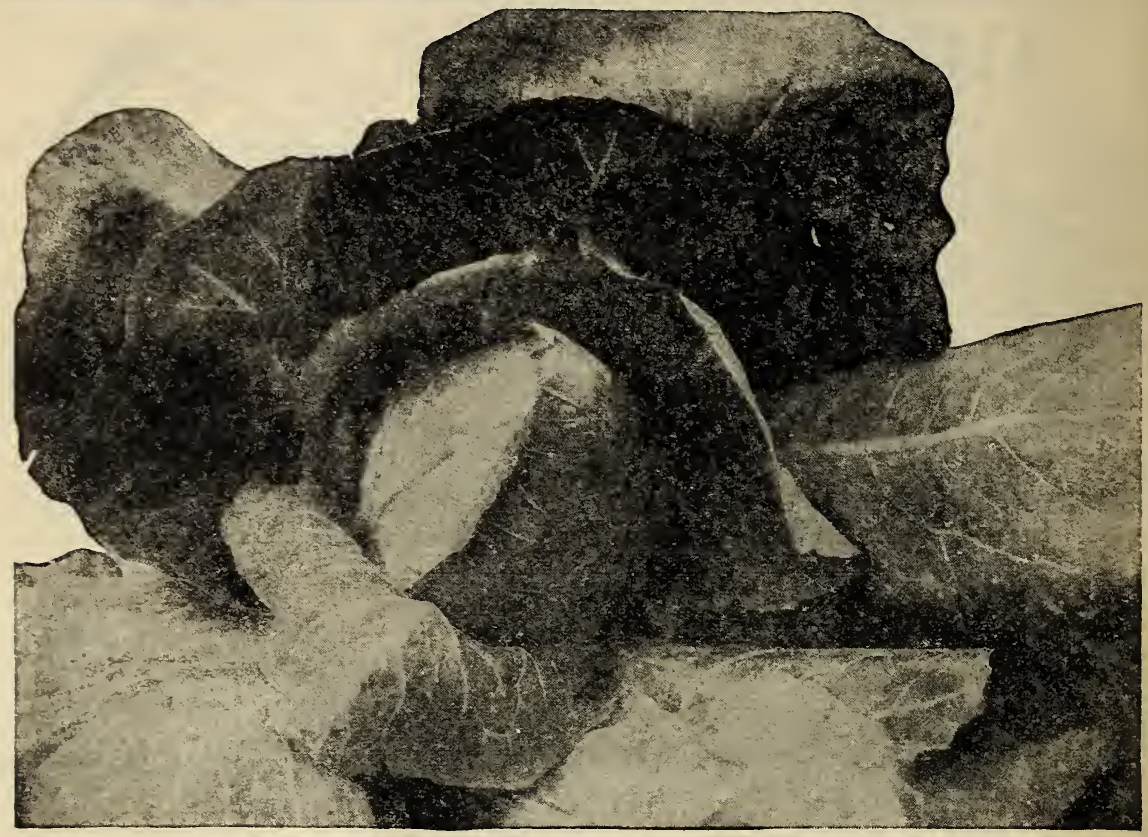

Early Jersey Wakefield Cabbage

\section{Cabbage Plants_- specialty! $\$ \$ \$$ Plant for Profit! $\$ \$ \$$}

Cabbage is a most profitable crop, though many good farmers don't realize it. Cabbage grows prolifically in all parts of the United States. Grow it for market as well as home use. Sell cabbages and make and sell your own sauerkraut. But like any other kind of stock, be sure to have good plants, for otherwise all your money and labor will go for naught.

For many years we have made cabbage plants our big business and in fact they were all we sold. Now we grow millions and millions of them and know how to grow them, pack them, ship them for our customers. Only good, strong, healthy plants with well developed root systems are shipped. Order your plants from us and be sure.

\section{Union Plant Company's are FROST PROOF!}

Our plants are grown in the open field and subjected to frost and freeze, consequently they are hardy and FROSTPROOF. We have known these plants to stand a temperature of 10 degrees above zero without injury. All plants are picked by hand and one at a time (NOT BY THE HANDFUL), counted and tied in bunches of 50. The roots are carefully packed in damp moss and wrapped in waxed paper, that keeps out the drying air. Thus the care we take plus the fine and frostproof plants, to give you the very highest quality of cabbage plants.

\section{Guarantee.}

If the increased yield of headed Cabbage from our plants, compared with the yield from cheaper plants of same varieties sold by others, planted at the same time and grown under the same conditions, is not worth more than the difference in cost, we will refund the entire purchase price. There is a reputation of over 10 years of honest dealing behind this guarantee. 

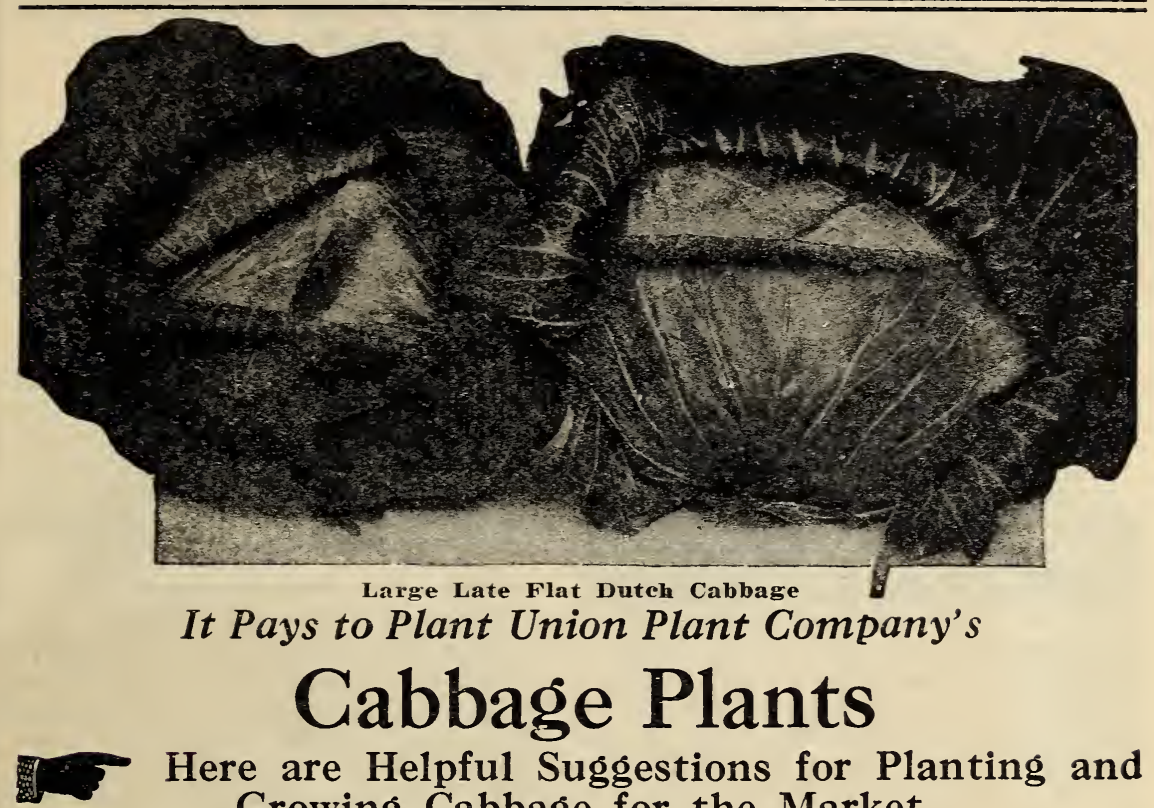

\section{Here are Helpful Suggestions for Planting and Growing Cabbage for the Market}

If you have it, select a piece of dark, medium low, well-drained land; break it up as thoroughly as you can, then pulverize well with a good clod-breaker or harrow. Lay off your rows thirty inches apart. Make up your bed by throwing two furrows together with a turn plow. Firm this bed by running heavy roller down same; set plants 16 inches apart, well down in soil so that plants have the entire stem up to the first leaves covered with soil. If stem is left exposed, freezing weather will cause them to split, maggots get in these splits and eat up through the stem and destroy the bud. Be sure and pack the soil good and tight about the roots and stem of plant. These plants should not be fertilized at all until two weeks before your regular spring weather opens up. The land must be rich for growing early vegetable crops, it being best to apply fertilizer in spring even though plants are planted in winter. About two weeks before your regular spring weather opens up, take a turn plow and throw a furrow away from plants in each alternate row, running the plow as near the plants as possible in this furrow. Drill your fertilizer at the rate of one-half ton to the acre; two weeks later treat the other alley the same way. In covering the fertilizer be sure to work the soil under the leaves of the plant. After this time use your judgment; should the spring be wet, you want a high bed; if it be dry you want the ground as level as possible. Provided the instructions are followed, you can sit back and watch the finest crop of cabbage you have ever grown.

TREATMENT OF PLANTS ON ARRIVAL-If the plants cannot be set out the same day they are received, take them from the crate immediately, dip the roots in water and hill out into the ground, spreading the bunches out a little. In no case should they be left in the crate.

TWICE AS UUCH CABBAGE PER ACRE-We know how to produce good plants; you'll find no runts or weaklings among those you purchase; practically every one makes good. You'll easily get from 6 to 10 tons of Cabbage for each acre you plant.

When the plants come to you they look stunted and wilted, but don't bother about the appearance; plant all of them just the same. Place them in the ground a month before you'd set out home-grown plants, and then forget about them. Order now and be sure of Cabbage profits this season. Our guarantee protects you perORDER YOUR PLANTS NOW-USE THE HANDY ORDER BLANK page. Prizehead Variety, see Inside Front Cover. For other varieties, see next page. 


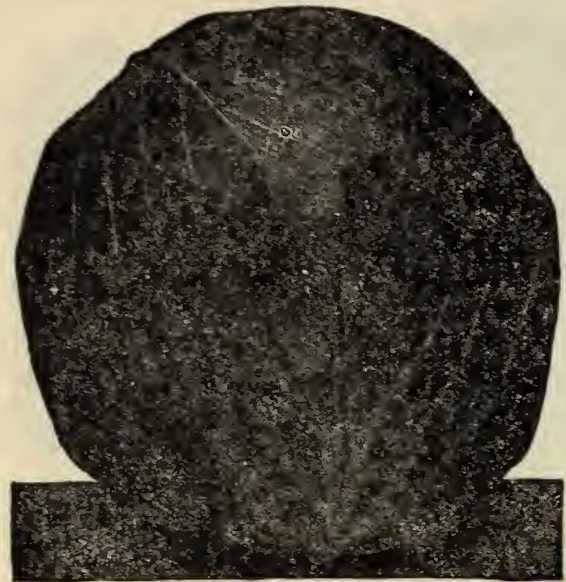

Copenhagen Market Cabbage

Copenhagen Market-A big yielder, extra early. Fine round heads, averaging 8 pounds; very solid; small core. Plants are short-stemmed, heads being produced almost on the surface of ground. Ready for market as early as Jersey Wakefield and heavier yield per acre.

Early Jersey Wakefield-A favorite with market gardeners and truckers to grow for earliest Cabbage, both for home market and shipping. Makes compact, solid, blunt-pointed heads; small leaves, permitting close planting. Very hardy, not only to resist cold but other unfavorable conditions. Our plants are properly grown and selected with care.

Charleston Large Type WakefieldExtra large, hardy, good shipper. A splendid strain of Jersey Wakefield, about a week later, with heads twice as large and weighing 8 to 12 pounds more. A good keeper and a strong favorite among southern growers as a main crop. May be planted as a second crop,

\section{Varieties of CABBAGE PLANTS Ready to Ship!}

Frostproof plants. You can set them out earlier than others. Our special built crates, used in shipping Cabbage and Onion plants, assure safe arrival of plants in first class condition. Safe delivery guaranteed. (For Prizeheat variety, see Inside Front Cover.)

to mature in autumn, if desired.

Succession-Largely a market growers' variety in many parts of the South, being used almost exclusively for shipping crops. Rather large size, well flattened on top. Firm and solid, a sure header and good shipper to North. Matures about ten days later than Early Summer and Early Flat Dutch, but nearly double their size.

Large Late Flat Dutcl-An excellent keeping variety, more extensively grown for main crops than any other variety. This is one of the oldest varieties and needs no recommendation. Heads large, broad, roundish flat; solid and of good quality, tender and fine grained. $\mathrm{Re}-$ sists heat splendidly.

Early Flat Dutch-One of the most reliable cabbages for early spring planting. Plant is short-stemmed, upright, and having comparatively few and short leaves, the rows can be set close together. Heads large, solid, crisp and tender. Excellent for home use and to follow Wakefield and Succession.

\section{Prices on Cabbage Plants Shipments from November 1st to June 15th}

\section{Special for $\$ 1.25$}

200 cabbage plants of any of our varieties (except Prize head), your selection or ours, and 500 onion plants of any of our varieties, sent postpaid for \$1.25. You'll save money.
(By Parcel Post, Prepaid)

100 Plants......80.50

200 Plants....... $\mathbf{. 7 5}$

300 Plants....... $\mathbf{1 . 0 0}$

500 Plants...... $\mathbf{1 . 2 5}$

1,000 Plants....... 2.00

5,000 Plants...... $\mathbf{7 . 5 0}$

5,000 Plants and over, by express collect, per 1,000 . 1.00
Special for $\$ 1.75$

400 cabbage plants of any of these varieties (except Prize he a d), your selection or ours, and 700 onion plants of any of our varieties, sent postpaid for $\$ 1.7 \dot{0}$. You'll save money. 
WING to the recent freeze which destroyed or killed nearly all the cabbage plants in the United States, we will be unable to ship Cabbage Plants again until February 15th or 20th. Onion Plants were not injured and can be shipped promptly in any quantity.

\section{Union Plant Company} TEXARKANA, ARK. 


\section{How to Grow Bermuda Onions}

\section{From Union Plant Company's Onion Plants}

Now here's a fine crop to grow-ONIONS-Bermudas. And here's how to grow them. Read and heed. We have been selling choice onion plants for years and grow the plants by the hundreds of acres. We recommend plants as against sets, for reasons mentioned below, and as our little boy says, in slang of today, "we know our onions."

First-You will find the Onion Plant the easiest of all plants to grow. They will keep for weeks, after being pulled if not allowed to become Heated or Wet. (Keep them dry and give plenty of air if not ready to plant upon arrival.) Like everything that grows, the richer the land the heavier the yield. You will have very satisfactory results cn all classes of soil.

Second-Prepare land the same as you would for any other truck. Te prefer to plant in rows 14 to 16 inches and plant 4 inches apart in the row. If you do not have plenty of rain or irrigation, plant in 24 -inch rows and 6 inches in the row for the best results.

Third-How to Plant: Sharpen a wood stick, making a hole about two inches deep, place the plant in as you withdraw the stich and press dirt firmly with stroke from stich.

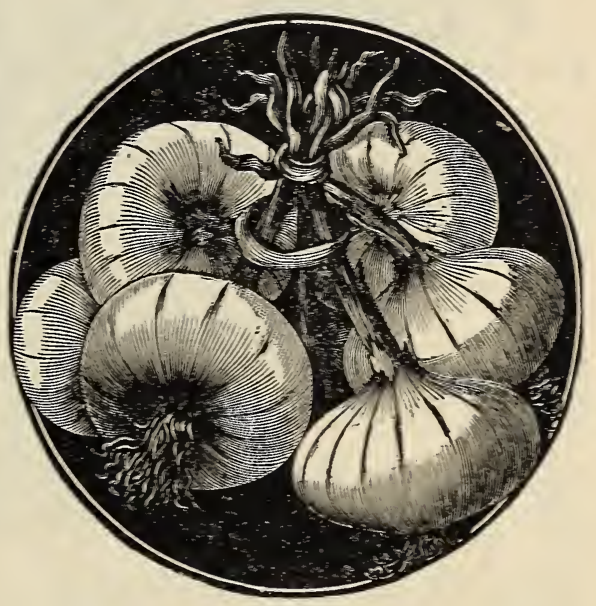

Fourth-Cultivate very shallow as the onion roots grow near the surface and should not be disturbed. About all the cultivation needed is scratching to kill weeds.

Fifth-Best harvesting methods when about 60 per cent of tops droop or are soft at neck, just above onion, pull them up, leave them lying in sun for two or three dars, giving tops a chance to descend into the onion, thereby increasing in weight and firmness about 20 per cent. After this is done place onions in cool place, with tops and roots cut off about one inch from onion. For keeping for home use, let tops and roots remain and tie in bunches and hang up in cool place. Be careful that the place is not full of light, for light will turn the Crystal Wax green, the light will not hurt the Yellows. You will find they will keep for months in this manner.

Our Bermuda Onion Plants make larger, more to the acre of ground, keep better and are cheaper than sets. They are not hot, and are sweeter and in every way ten to one better than Onions grown from sets. Try a thousand or more this year. You will never set out another set. Ask anyone who has tried them.

Onion Plants make quicker, sweeter, larger, keep better, not strong and hot, and make more to the square foot. They grow large and saucer-shaped. They have very small tops and make large onions. They are cheaper- $\$ 1.00$ worth of onion plants will set a.much larger acreage than $\$ 1.00$ worth of sets.

USE PLANT ORDER BLANK IN BACK OF BOOK. FOR VARIETIES AND PRICES, SEE NEXT PAGE.

\section{WON FIRST PRIZE WITH OUR PLANTS}

"Please send me 1.000 Crrstal Thite Bermuda Onion Plants. Jan. $31,1927$. PRIZE AT TOWNSHIP FAIR AND SECOND AT COUNTY FAIR. I planted last rear 3,000 of, your plants and after eating all we wanted, harvested 24 bushels of onions." 


\section{Set Out \\ Union Plant Company's BERMUDA

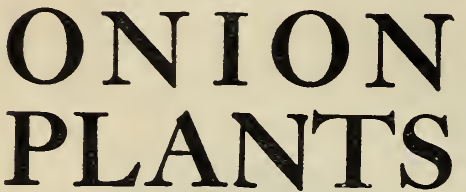

For Larger and Better Flavored Onions

Iou'll get a better start, produce larger, sweeter and MORE onions by planting the plants. These Bermuda plants make quicker and yield large saucer shaped onions, with very small tops and quite large onions-not hot and strong-and they keep better. Our plants are grown out in the open fields, where the frost doesn't get them but just cold enough to make them tough and ready for field setting. Our reputation is also behind these plants-we grow them and know what we've got. You grow them and you'll know too. See preceding, page for more information as to "How."

White Crystal Wax and Yellow Bermuda-These are the onions that are so highly prized because of their earliness. The White Crystal Wax is a rather new variety. Large pure white flat onions, popular with southern onion growers. Mildest and sweetest of onions, fine for slicing. The Yellow Bermuda is the same as the Crystal Wax except it has a yellow skin. This, however, is the better keeper because the light does not penetrate in the onion as with the white-thus a point in its favor. In ordering please state your preference.

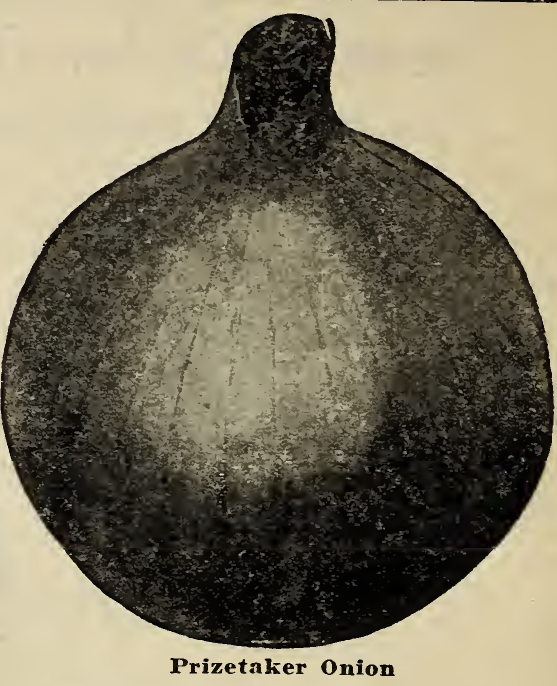

Prizetaker-The King of the Yellow Onions, a big yielder and a sure cropper. The most productive and largest of all the yellow globe onions. Always grows to a uniform shape, which is a perfect globe. Invariably attracts attention on the markets on account of jts size and beauty and is sure to bring a better price than other onions. They are even more attractive than the large Spanish onions, in fact these are excellent substitutes. Plants grown from American-Grown seed.

SHIPMENTS FROM NOVEMBER 1ST TO JUNE 15TH. Order now for immediate or advance shipments.

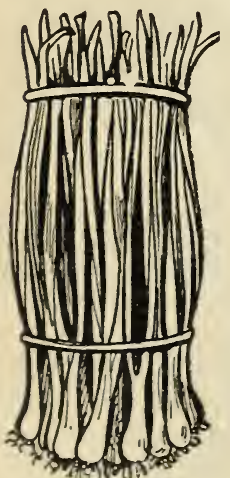

Here's the way the plants come to you-In bunches of 100. Note the unlformity.

\section{Prices on Onion Plants}

(By Parcel Post-Sent Prepaid)

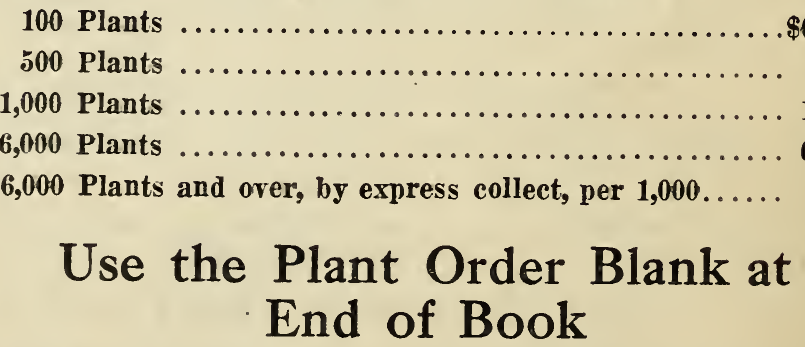

Our special built crates used in shipping Onion and Cabbage Plants insure safe arrival of plants in first class condition. 


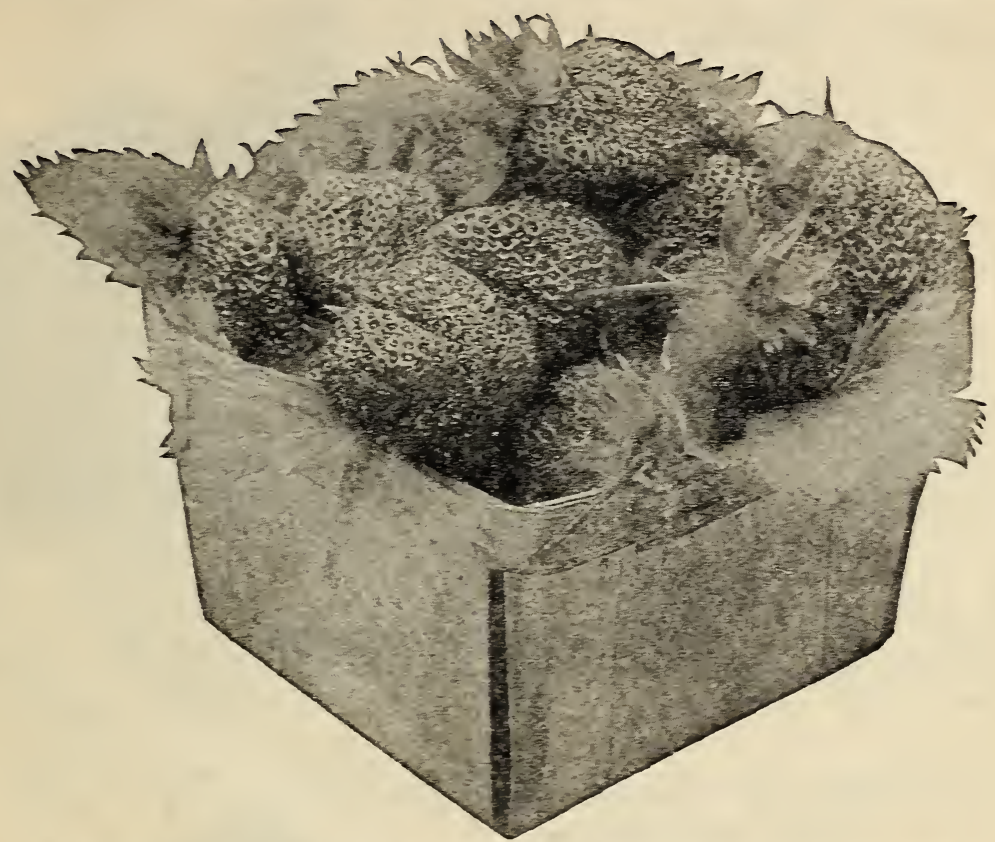

\section{Here's a "Big-Money-Per-Acre Crop"}

\section{GROW STRAWBERRIES!}

If you want your land to produce big returns, plant strawberries. Profis rary from $\$ 125$ upwards to $\$ 1,500$ per acre and we have known of cases where $\$ 2.000$ per acre had been made clear morey. One man in Texas made $\$ 21,000$ off of three acres in four crops. Strawberries should put you on your feet in good shape. But better the price and plants to grow better berries-the choicer the fruit, the

Our berries are grown in Arkansas and Arkansas berries have a nation-wide reputation. Following are the leading, varieties, with prices. If you're in doub as to the bind to plant, write us to make suggestions.

\section{Price List of Choice Arkansas Berry Plants}

Sent Post Paid-

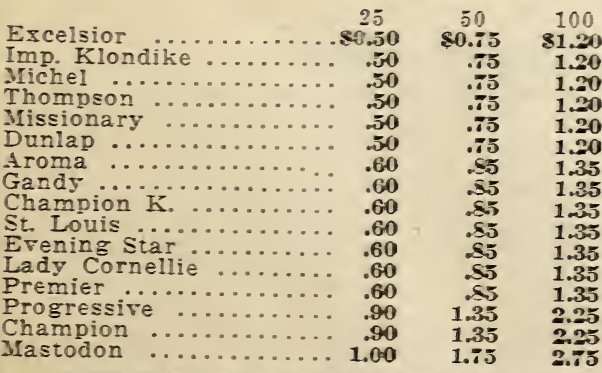

\begin{tabular}{|c|c|c|c|c|}
\hline 250 & 50 & 1,000 & 5.000 & \\
\hline$\$ 1.50$ & $\$ 2$. & 84.00 & $\$ 17.50$ & $\$ 30.00$ \\
\hline 1.50 & & 4.00 & 17 & 30.00 \\
\hline 1.50 & 2. & 4.00 & & 30.00 \\
\hline 1.50 & 2. & 1.00 & & 30.00 \\
\hline 1.50 & 2. & 4. & & 30.00 \\
\hline $\begin{array}{l}1.50 \\
1.75\end{array}$ & 2. & 4. & & 30.00 \\
\hline 1.75 & 2.8 & 4.50 & & $\begin{array}{l}35.00 \\
3.5 .00\end{array}$ \\
\hline 1.75 & 2.8 & 4.50 & 18 & 35.00 \\
\hline 1.75 & 2. & 4.50 & 18 & 35.00 \\
\hline 1.7 & 2 & 4.50 & 50 & 35.00 \\
\hline 1. & & 4.50 & 50 & 35.00 \\
\hline 1.8 & & 4.50 & & 35.00 \\
\hline $\begin{array}{l}3.0 \\
3.0\end{array}$ & & & & 60.00 \\
\hline 3.50 & & 12.50 & & $\begin{array}{r}60.00 \\
110.00\end{array}$ \\
\hline
\end{tabular}

ORDER NOW IF YOT WATT ATT OF blank in back of this catalog. ANX OF THESE FINE PLANTS. Tse plant order 


\section{Tomato Plants}

Here are other fine plants you may need. Even though you may not be ready now, place order in advance for future delivery.

Gulf State Market-100 Days - Tery productive; excellent shipper vecause of tough skin. Globular $\mathrm{s}$ ha $\mathrm{pe}$, free from cracks. Color, purple and pink. Hardy vine.

Norton Wilt Resistant-115 D a $\mathbf{y}$ s-Introduced by U. S. Dept. of Agriculture for wiltresistance. Medium size fruit, smooth and solid. A maincrop, scarlet-fruited variety.

Early Detroit-110 Days-A smooth globular shaped tomato of good quality. Large, early. productive, solid variety, flesh purple.

Livingston's G 1 ob e - Very productive, extra good allround tomato, distinct globe shape. Always smooth, firm-

fleshed, few seeds. Color, purpolish pink. A very good keeper.

June Pink-90 Days-The earliest pink variety on the market. Solid fruit, borne in profusion. A large, red, smooth tomato, medium size, nearly round.

McGee-Of Texas origin. Bright crimson, solid, good flavor. Especially recommended for black land. Claimed to yield where other varieties fail.

Earliana-90 Dars-The earliest, large, red, smooth tomato on the market. Healthy vines

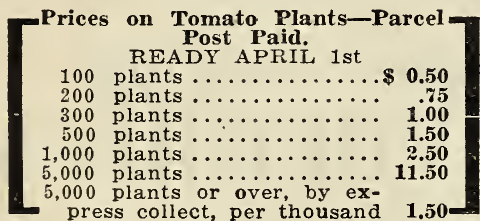

\section{Egg Plants}

Black Beauty-125 Days-An early fruit and quick seller because of black and fadeless color.

New York Purple-130 Days-Probably oldest and best known variety. Early and produces 4 to 6 large, excellent fruits.

\section{[For Prices, See Below]}

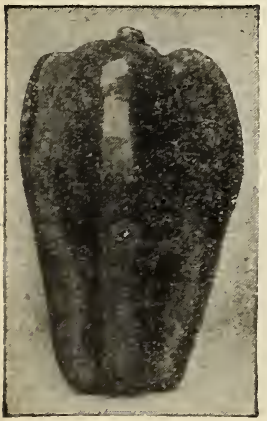

\section{Pepper Plants}

Chinese Giant-140 Days-Laro chunky peppers, bright scarlet when ripe, mild to eat, beauties to look at. 4 to 5 inches across and $4 \frac{1}{2}$ inches long.

Bull Nose or Large Bell-120 Days-Old standby. Large fruit, thick flesh, with broad end, almost square. Deep green when young, bright crimson when ripe. Mild flavor. Plants, 2 feet high.
Ruby King-110 Dass-General favorite; $\mathrm{m}$ os t generally used. Longest of the largest! Brilliant red, 10 to 15 fruit to plant. Flavor sweetish; free from heat. Resists decay longer.

Long Red Cayeune-100 DaysVery hot, bright red pepper, long and slender. Fruit about 3 to $31 / 2$ inches long, $1 / 2$ inch across at stem end twisted to a point.

Prices on Egg and Pepper Plants-Parcel Post Paid READY APRIL 1st

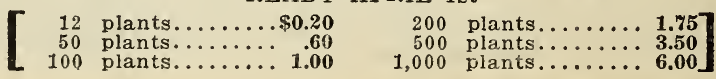




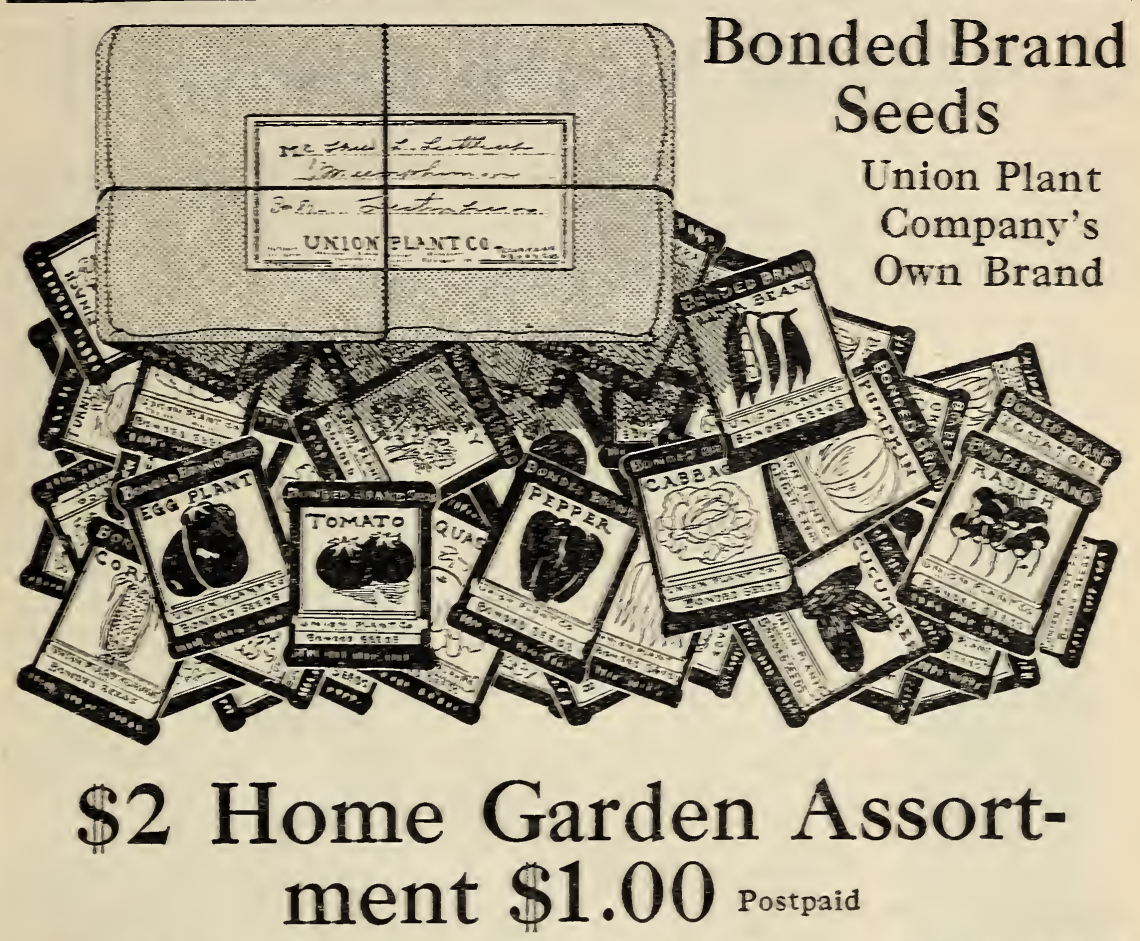

In order that you may become better acquainted with BONDED BRAND SEEDS-our own pet brand, well give you a choice assortment wherebr youll not only get good quality seeds, but save half besides. Here is a fine selection of regetable seeds, principally, a Home Garden Assortment of fresh and new crop seeds. Regular full size packet-ibirty in all. A \$2 assortment for \$1, sent postpaid. Just ask for our Special Assortment. Satisiaction-or jour money back. Our word is our BOND:

\section{Here Is What You Get In Our Get-Acquainted Offer :}

1 Pkt. Egg Plant, Black Biauty..... je

1 Pkt. Beans, Large White Lima....10c

1 Pkt. Sweet Corn, Stowell's Ever-

green .......................

2 Pkt Cabbage, E. J. Takefeld....10e

2 Pkt. Cabbage, Late Flat Dutch....10e

2 Pkt. Mustard, Southern Giant

Curled ....................

2 Pkt. Cucumber, Long Green.......10e

1 Fkt. Beet, Early Blood Turnip.... se

1 Pkt Pepper, Bell.................10e

1 Pkt. Lettuce, Curled Simpson...... sc

1 Pkt. Okra. White Telret.........10e

1 Pkt. Radish, Scarlet Turnip...... se

1 Pkt. Radish, Icicle ............ 5e
1 Pht. Turnip, Eariy White Milan... ac

1 Pkt. Turnip, Purple Top Globe... 5. 5c

1 Pkt. Cantaloupe, Rocky Ford..... 5e

1 Pkt. Squash, White Bush..........10e

1 Pkt. Spinach, Bloomsdale ........ re

1 Pkt. Tomato, Beaut ............ 5e

1 Pkt. Tomato. Store ............ sc

1 Pkt. Pumpkin, Larga Cheese...... 5e

1 Pkt. Watermelon, Watson ........ 5c

1 Pkt Onion, Red Wethersfeld.... . Dc

1 Pkt Onion, Priz $=$ Taker..........10e

1 Pkt. Scarlet Sage ...............10e

I Pkt. Pars?ey, Mross Curled........ 5c

Total

$\$ 200$

Entire assortment, regular price $\$ 200$. Special price, \$1.00. No subfxs stitution allowed. This is listed on seed order blank at back of eataleg. 


\section{GARDEN PEAS "BONDED}

CULTURE-The pea is hardy and endures cold well, either in or above the ground. It is best to sow the earliest varieties as soon as possible (February) in warm, light soil, prepared the previous autumn or winter. The main crop may be sown about two weeks later and on somewhat heavier soil. Sow Peas in drills about 2 to 3 inches deep, in rows $2 \frac{1}{2}$ to $3 \frac{1 / 2}{2}$ feet apart. In garden culture sow in double rows, 10 inches apart. One quart will sow 100 feet of drill. All wrinkled varieties should not be planted until March.

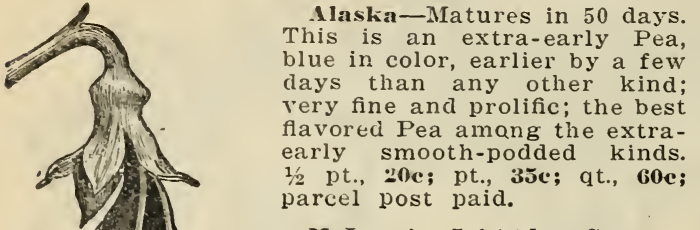

MeLean's Little GemHardy, prolific, uniform in habit of growth. Pods medium size and well filled. Medium early. Height eighteen inches. $1 / 2$ pt., 20c; pt., 30e; qt., 60e; parcel post prepaid.

Thomas Laxton - La rge podded, extra early Pea. This fine early Pea was raised by crossing Gradus with the Alaska. In earliness the Thomas Laxton is only two or three days behind the Alaska, but the pods are very much larger, containing on the average seven or eight large, sweet, wrinkled Peas of the very richest flavor. The vines attain a height of from three, to three and onehalf feet. It is of hardier constitution than the Gradus, and is earlier and of darker colored pod. In flavor this Pea is unsurpassed. $1 / 2$ pt., 25c; pt., 40c; qt., 70c; parcel post paid.

Gradus-Ripens early; vines about three feet high; bears profusely. The pods almost as large as those of Telephone. $1 / 2$ pt., 20e; pt., 35e; qt., 60e; parcel jost paid.
First and Best Extra Early -The best of the whiteseeded extra-early sort. For earliness and purity is without a rival. Pods short but well filled. Height, two and a half feet. $1 / 2$ pt., 20e; pt., 35e; qt., 60e; parcel post paid.

Laxtonian-18 inches. The largest-podded of the dwarf wrinkle peas. A splendid new variety, becoming a favorite with those who grow for the market or for the home garden. Laxton i $n$ matures earlier and is very prolific. $1 / 2$ pt., 25c; pt., 40c; qt., т0c; parcel post paid.

Champion of England-It grows 4 to 5 feet high and requires support, and large crop production more than repays any extra labor required. $1 / 2$ pt., 20e; pt., 35e; qt., 60e; parcel post paid.

Melting Sugar-Edible pod or sugar pea, 5 feet. Large, broad pods. Cook pod like snap beans. 1/2 pt., 25c; pt., 40e; qt., Foc; parcel post prepaid.

Large White MarrowiatHeight 5 feet. Vine and foliage stout, deep green. 1/2 pt., 20e; pt., 30c; qt., 55e; parcel post prepaid.

Telephone - All the vines are tall, about four feet high, with large leaves, and producing an $\mathrm{a} b \mathrm{~b} \mathrm{ndance}$ of pointed pods of largest size, often four and one-half to five inches long, filled with very large peas, which are tender and sweet. 1/2 pt., 20e; pt., 35e; qt., 60c; parcel post paid.

\section{Artichokes}

Sow in drills in Marcl 8 or 10 inches apart, when the plants are well up, transplant in rows 4 feet apart and 2 feet apart in rows.

Green Globe FrenchPkt., 10c; oz., 50c; parcel post paid.

Kohl-Rabi-Early White Vienna-This is the best and earliest variety for table use. Pkt., 5c; oz., :5c; 1/4 ib., 75c; 1 lb., \$2.25; parcel post paid. 


\section{Bonded Brand Beans}

\section{Dwarf or Bush Beans}

Culture-These can be plarted any time from April 1st to September 1st. Sow 3 inches apart in rows, and have the rows $2 \frac{1 / 2}{2}$ or 3 feet apart. One quart will sow 200 feet of row.

Black Valentine - The pods are dark green, long, straight. It is also one of the earliest varieties. $1 / 2$ pt., 20c; pt., 35̄e; qt., 60c; parcel post paid.

Bountiful-Green pods are long. broad, thick, flat, meaty, meltingly tender. $1 / 2 \mathrm{pt}$, 29c; pt., 35̃c; qt., 60c; parcel post paid.

Burpee's Stringless Green Pod-Pods semiround, perfectly stringless, tender and brittle. 1 '́, pt., 20e; pt., 35̄; qt., 60c; parcel post paid.

Full Measure-This magnificent roundpodded bush bean bears long, round green pods, stringless. $1 / 2$ pt., 20e; pt., 35e; qt., 60e; parcel post paid.

\section{Dwarf Wax Podded}

Giant Stringless Green Pod-Fine for home use or market. The pods are round, meaty, perfectly stringless. 1/2 pt., 25e; pt., 40c; qt., Foc; parcel post paid.

Improved Red Valentine-The pods are round, about 4 inches long, fleshy, crisp and tender. 1'2 pt., 20c; pt., 35̈c; qt., 6Cc; parcel post paid.

Longfellow-The pods that average more in length are almost entirely stringless. Prices 1/2 pt., 20c; pt., 35c; qt., 60c; parcel post paid.

Tennessee Green Pod-rields the longest and largest pods of any Bush Beans, flat in shape but of fine flavor. $1 / 2$ pt., 20c; pt., 35c; qt., 60c; parcel yost paid.

Culture-These can be planted with safety

Sow 3 inches apart in rows and have the row
Currie's Rust Proof Wax-Pods light yellow, similar in shape to Golden Wax, $5 \frac{1 / 2}{6}$ to 6 inches long.

Improved Golden Wax-Vines vigorous and hardy; pods broad, flat and of a golden yellow color. 1/2 pt., 20c; pt., 35e; qt., 60c; parcel post paid.

Prolific Black Wax-A popular variety,

any time from April 10th to September 1st. or 3 feet apart, cover seeds two inches. waxy yellow; tender, productive. 1/2 pt., 25̌c; t., 35e; qt., 60e; parcel post paid.

Round Pod Kidney Wax-The best round podded variety. ${ }^{1 / 2}$ pt., $25 \mathrm{c}$; pt., $40 \mathrm{c}$; qt., roc: parcel post paid.

Sure Crop Wax-A recent introduction similar to Currie's Pust Proof. Pods are longer, thicker through and entirely stringless. pt., 25c; pt., 40c; qt., i0c; parcel post paid.

\section{Bush Limas}

One Quart Will Plant 200 Feet of Drill

Culture-Plant in May in light rich soil, in drills two feet apart. dropping the seeds about one foot apart in the row, and cover two inches.

Burpee's Improved Bush LimaPods as large as those of the Pole Lima, and contain beans of the best quality. $1 / 2$ pt., 25c; pt., $40 \mathrm{c}$; qt., Foc; parcel post paid.

Fordhook Bush Lima-An immense yielder, with handsome

\section{Green and Wax Podded Pole Beans}

Culture-Plant in May and June in rows 4 feet each way; 5 in a hill. Can be planted in corn or by poles, 8 feet high. One quart will
plant about 200 hills.

Kentucky Wonder-The yield is great, the quality is good. It bears in 65 days from planting. should be kept picked so that it will continue bearing until frost. 1/2 pt., 20c; pt., 35̃c; qt., 60c; parcel post paid.

McCaslin Pole Bean-The pods average 8 to 10 inches in length, are flat, slightly curved and of a rich green color. Makes an excellent snap bean and the whiteshelled beans are unsurpassed for winter use. $1 / 2$ pt., 20c; pt., 35̄e; qt., 60e; parcel post paid.

Red Speckled Cut Short-This variety is the best bean to plant

\section{Pole Lima Beans}

Pole Speckled Lima-Used in the South xhere it is one of the most prolific of pole limas. The dry beans are of medium size, milky white and blotched. Pkt. $10 \mathrm{c} ; 1 / 2 \mathrm{lb} ., 20 \mathrm{c} ; 1 \mathrm{~b} ., 35 \mathrm{e} ; 1 / 2$ pt., $25 \mathrm{c}$; pt.; $40 \mathrm{c} ;$ qt.. $70 \mathrm{c} ;$ parcel post paid

Large \%hite Lima or Butter BeansThe ole favorite and of fine flaror. Pkt. 10c; $1 / 2$ lb., 20c; 1b., 30c; $1 / 2$ pt. $20 \mathrm{c}$; Dt., $35 \mathrm{c}$; qt., 60e; parcel post paid.

King of the Garden Lima-This is a decided improrement ofer the LARGE in corn hills. It is hardy, late and is a heavy yielder. 1/2 pt. 20c; pt., 35̃c; qt., 60c; parcel post paid.

White Creaseback - Especially valuable on account of its earliness. $1 / 2$ pt., 20c; pt., 35c; qt. $60 \mathrm{c}$; parcel post paid.

Southern or Striped CornfieldThis is the real Cornfield Bean about. It will produce the kind of results that you'll expect. pt., 20c; pt., 35̃c; qt., 60c; parcel post paid.

WHITE, being a strong grower, rers pro ductire and bearing large, well filled pods. Pkt., 10c; $1 / 2$ lb., 20c; lb., 30c; $1 / 2$ pt., 20c; pt., 35c; qt., 60c; parcel post paid.

Small Carolina or Sieva Lima-This is a small tspe of the pole limas. It matures quickly, produces immense crops, and makes an excellent bean for winter use. Pkt 10c: 15 lb

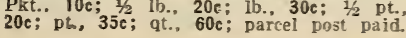
that you have read so much

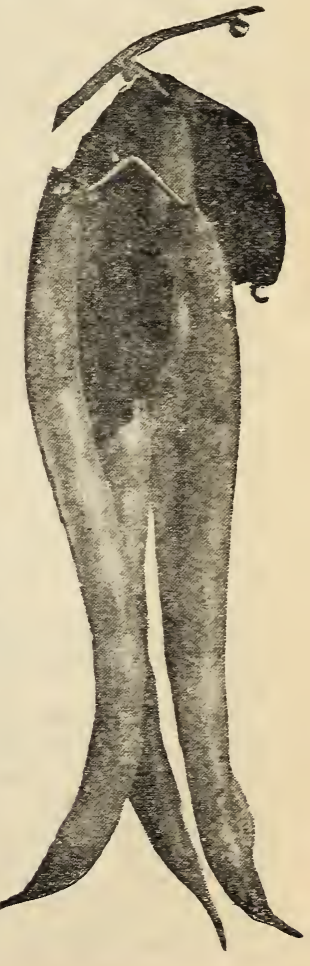




\section{Bonded Brand Cucumber Seeds}

Culture-For very early crop plant in hot beas; for later crop plant from April to July in rich, well-manured lills, 4 feet apart, 10 seeds in hill; thin to two or three plants. One ounce to 50 hills.

Improved Early White Spine-An improved strain of the White Spine; good for forcing or outdoors. Pkt., 5̃e; oz., 15c; 1/4 lb., 35e; 1 lb., \$1.00; parcel post paid.

Improved Long Green-A fine bearer of superior quality. Pkt., 5e; oz., 15c; 1/4 lb., 40c; 1 lb., \$1.25; parcel post paid.

Japanese Climbing-This is a strong and vigorous grower, fine for pickling. Pkt., 5c; oz., 15c; $1 / 4$ lb., 40c; 1 lb., \$1.25; parcel post paid.

Gherkin-Used only for pickling. Pkt., 5c: oz., 15e; $1 / 4$ lb., 40e; 1 lb., $\$ 1.25 ;$ parcel post paid.

Cnion Plant Co.'s Pickling-Fine for market gardeners. Medium length, pointed at each end; has large spines, deep green, very prolific. Good for pickling. Pkt., 5e; oz., 15e; 1/4 lb., 35e; 1 lb., \$1.00; parcel post paid.

Evergreen White Spine-An extra early, darl green, White Spine strain, producing very

uniform fruit in great abundance. The vine is vigorous and produces fruit for a long season. Fruit averages from eight to ten inches long and is of the finest quality. Pkt., 5c; oz., 15c; $1 / 4$ lb., 40c; 1 lb., $\$ 1.25$; parcel post paid.

Early Green Cluster-A very popular early cucumber, producing its rruit in small clusters near the root of the plant. Average length is about 5 inches, skin prickly. Pkt., 5c; oz., 15c; $1 / 4$ lb., 35c; 1 lb., \$1.00; parcel post paid.

Early Fortune-One of the best of the White Spine type, is becoming very popular among the market men of the South. Pkt., 5c; oz., $15 c$; $1 / 4$ lb., $40 \mathrm{c}$; 1 lb., \$1.25; parcel post paid.

Davis Perfect-Possesses all the merits of the best slicing varieties; wonderfully uniform in shape and exceedingly productive. Their handsome shape and fine dark green color commands the highest price of the market. Pkt., 5c; oz., 15c; $1 / 4$ lb., 35c; 1 lb., \$1.00; parcel post paid.

\section{Bonded Brand Tomato Seeds}

Culture-The seed should be sown in March in a hot bed or green house, or may be sown in a box and kept inside the window of a room where the night temperature is not less than 65 degrees. The plants should be thinned out in the bed so as to give them plenty of room or they will be weak and poor. About the middle of May the plants may be set in the open ground from 4 to 5 feet apart each way.

Acme-Early and bears fruit until cut off by frost. Fruit is purplish, always round, smooth and of good size, and is borne in clusters of four or five; free from cracks and stands shipment well. Flesh is solid and of excellent flavor. Pkt., 5c; oz., 30c; ${ }_{1 / 4}$ lb., 90c; 1 lb., \$2.75; parcel post paid.

Beauty-Is early, of good size, smooth, a good bearer and the quality is all that could be desired. The fruit is a purplish red color. Pkt., 5c; oz., 30c; $1 / 4$ lb., 80c; 1 lb., \$2.75; parcel post paid.

Bonny Best-An excellent extra-early variety, maturing between Earliana and Chalk's Early Jewel. Medium size, scarlet, smooth round shape. Pkt., 5c; oz., 40c; 1/4 lb., 90c; 1 lb., \$3.00; parcel post paid.

Dwarf Ponderosa-It is much the largest fruited of all dwarf tomatoes. The color is a rich purple crimson. Pkt., 10c; oz., 50c; $1 / 4$ lb., $\$ 1.50 ; 1$ lb., $\$ 5.00 ;$ parcel post paid.

Early Detroit-The largest and best of the early purplish tomatoes. Fruits very smooth, nearly globe-shaped, firm and of excellent quality. Is a better yielder and more vigorous than Acme. Not only are more fruits produced, but they average more nearly globeshaped, are heavier, and are equally as firm, smooth and suitable for shipping. Pkt., 5c; oz., 35c; $1 / 4$ lb., \$1.00; 1 lb., \$3.00; parcel post paid.

Greater Baltimore (110 Jays) - A main crop variety; fruit large and brilliant red in color. Ripens evenly to the stem. Pkt., 5c; oz., 30c; $1 / 4$ lb., 75e; 1 lb., \$2.50; parcel post paid.

Gulf State Market-One of the finest early glcbe shaped tomatoes yet produced. A very vigorous grower and withstands blight exceptionally well. Color deep purple pink, smooth skin, and free from cracks. Pkt., 5c; oz. 40 ; $1 / 4$ lb., $\$ 1.00 ; 1$ lb., $\$ 3.25$; parcel post paid.

Ponderosa, the Giant Tomato-Of the largefruited varieties, this is a gem. The vines

are strong in growth, and when planted in good soil and pruned to a single stem, the fruit reaches one pound in weight; tomatoes grow in beautiful uniform clusters. The fruit is mostly oblong in shape, usually ribbed, is deep purple color, has solid flesh of sweet flavor, and small seed cells. Pkt., 10c; oz., 50c; $1 / 4$ lb., $\$ 1.50 ; 1$ lb., $\$ 5.00 ;$ parcel post paid.

Livingston's Globe-Extra good, all-round tomato of a distinct globe shape. Always smooth, firm-fleshed and has but few seeds, especially the early fruits. Very productivethe plants have many short joints at which clusters of 3 to 7 fruits are formed. A remarkably good keeper and colors up handsomely; a purplish pink shade. Pkt., 10c; oz., 50c; $1 / 1$ lb., $\$ 1.50 ; 1$ lb., \$5.00; parcel post paid.

Matchless-The color is rich red. The skin is so tough that it makes a splendid keeper and shipper, and is less liable to crack in wet weather than any other large tomato. Unsurpassed for market or table; strong grower and very productive, bearing with undiminished vigor until frost. The fruit is free from core and the seed spaces comparatively small. Pkt., 5c; oz., 35c; $1 / 4$ lb., $\$ 1.00 ; 1$ lb., \$3.00; parcel post paid.

Stone-A large, bright-red tomato, very well known and highly regarded. One of the very best for canning purposes. Good also for slicing. Matures early and very uniformly. Vigorous and productive. Pkt., 5c; oz., 25c; 1 lb., 70c; 1 lb., \$2.75; parcel post paid

Earliana-A fine scarlet tomato. Ready for the market several days ahead of any other variety. Ripens uniformly and is a good yielder. Pkt., 5c; oz., 30c; $1 / 4$ lb., 75c; 1 lb., $\$ 2.50$; parcel post paid.

Red Pear-A small variety, fine for preserving: Pkt., 5c; oz., 35c; $1 / 4$ lb., 75e; 1 lb. \$2.75; parcel post paid.

Red Plum-Color bright red, excellent for preserving. Pkt., 5c; oz., 35c; $1 / 4$ lb., 85c; 1 lb., \$2.75; parcel post paid. 


\section{Bonded Brand Pumpkin Seeds}

CLLTLRE-Plant when the ground is warm in hills 6 to 10 feet apart depending on the rariety. Some rarieties like Large Cheese may be planted in the corn field. A plet. will plant about I0 hiils; one oz., about 50 hills; two to three lbs., to acre.

King of Mammoths-Mammoth Tours This $\overrightarrow{\mathrm{K}}$ of $\mathrm{M}$. grows to enormous size. often ? feet or more in diameter. The flesh is salmon color and finer grained than you would think, considering its size. To get this largest specimens allow only one vine to the hill and orly one or two pumpkins on the rine. Phi., 10e; oz., 20e; if Ib., 40c; 1 lb., \$1.25.

Tennessee sweet Potato-The flesh is white, fne-grained, solid and thick. Excellent for pies and custards. Prolific. Keeps well until late spring. Pkt., Je; oz.. 10c; 1/ 1b., 25e; 1b., 75e; 51 bs. @ 65e.

Large Cheese or Fentuchy Field- $(4)$ -This is the largest flat, solid, heary, cream-colored "sweet" pumphin, extensively grown in corn field for stoch, but is only second to the Sugar Pumplin for pies. Sells well on the market. It is

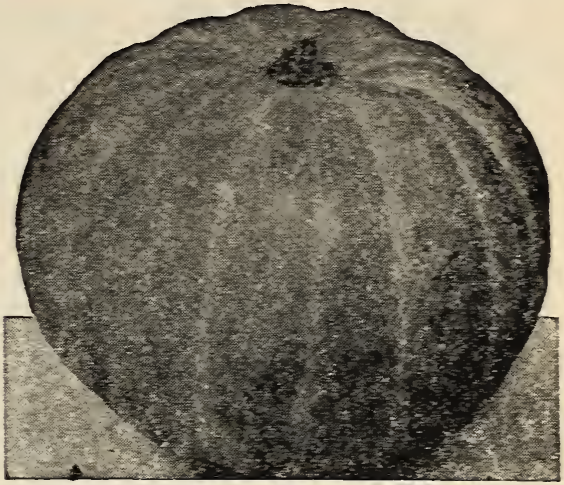

the rariety used by most canners. $\mathrm{h}$ eeps well in Winter. Plit., 5e; oz. 10c; 1 1b. 15e: 1 1b., 50c: 5 lbs. $A$ 40e.

Japanese Pie-(9) -The best crooknecked pumpkin. The flesh is salmon color, fine grained and more dry than some sweet potatoes when baked. First class for pies. etc. Pli. 5e; oz., 10c;

1. 1b., 30c; 1b., \$1.00.

\section{Bonded Brand Celery Seeds}

CULTCRE-For early celery sow in March or February, in hotbeds, in drills 4 to 6 inches apart and cover about 1/ inch deep. When fairly out of seed leaf transplant to another bed, thin out to? or 3 inches in the rom, and leave growing until needed to plant outside. In April plant the field in rows 18 to 20 inches apart, and set six inches in the row. In planting press the ground around the plants, but do not let any earth get into the heart. One ounce of seed produces 2,500 plants and it takes about 42,000 plants to set one acre if the rows are 2 feet apart.

Giant Pascal-This is a green leaved variety. It bleaches rery quickly after earthing up and is a beautiful yellowish white color, very solid and crisp, and of a sweet flaror which is not equaled by any other variety. The stalks grow broad and thick, a single plant making a large bunch. Under high cultivation this variety will give best satisfaction. Pkt.. 10c; oz., 25c; 1/4 lb., 90e; 1b., \$3.00.

Golden Seif-Bleaching-This is a beautiful plant of close habit, compact growth, and has straight and vigorous stalks. The ribs are perfectly solid, crisp, and brittle. Its delicate flavor is surpassed by no other variety and moreover it has the decided merit of being self-blanching to a very remarkable degree. Our stock of this seed is

\section{Bonded Brand Carrots}

Early Scarlet Horn-Stump root. Is popular for forcing and early outside sowing. Flesh deep orange, small tops. Pkt., 5e; oz., 10e; 1; 1b., 20e; 1b., 75e

Oxheart-A desirable variety on soil too hard and stiff for the longer growing sorts. Pht., 5e; oz., 10e; 1, 1b, 20e; 1b., 75 e.

Half Long Danvers-Improred stock. One of the most productive for field culture. Pkt., 5c; oz., 10c: 11 1b., 20c; 1b., 75e.

Long Orange-The best late rariety for field culture. Pkt., 5c; oz., 10c; 1; lb., 20e; 1b. 75e.

selected with special care in France. Pkt., 10c; 1,i oz., 75e; oz., \$1.25; $1=1 \mathrm{~b}$., $\$ 4.00$.

White Plume-This celery is valued because the stalks and portions of the inner leares and heart are white; by simply tying up the stalks and drawing up the soil with the hoe the work of blanching is completed. It is ornamental, tender, crisp and of good flaror, and very early. Pkt., 10c; oz., 25e; li 1b., 75c; 1b., \$2.50.

Celeriac or Turnip-Rooted Celery

Grown exclusirely for its roots, which are turnip shaped, very smooth, tender, and marrow-like. The roots are cooked and sliced and eaten with rinegar, they make an excellent salad. Are used for seasoning meats and soups. Pkt., 10e; Oz., 25e; $1 / 4$ lb., soc.

\section{Bonded Brand Asparagus}

Asparagus seed-Sow out doors in February and March in 18 in. rots, dropping two seeds every six inches, cover seeds one inch. One ounce will sow $50 \mathrm{ft}$. of row and produce two hundred plants.

Washington Pedigree Asparagus Seed -Pkt., 10e; oz., 30c: 1// 1b., \$1.00; 1 lb., \$3.00: parcel post paid.

Palmetto Asparagus Seeds-Plit., 5e; oz., 10c: $1 \frac{1}{=} 1 \mathrm{~b} ., 30 \mathrm{c} ; 1$ 1b., 90c: parcel post paid. 


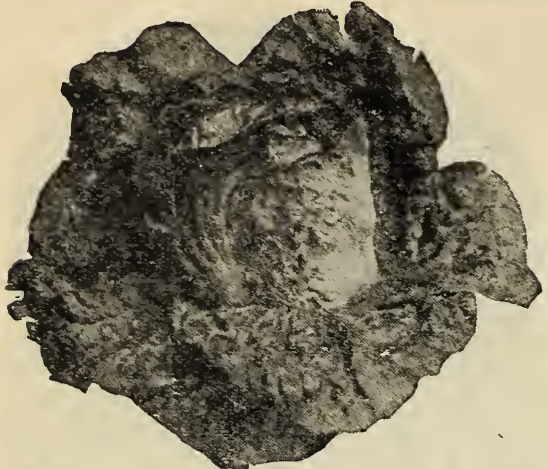

Culture-One ounce will produce 3,000 plants. For early use sow under glass in January or early February, and transplant as soon as the ground can be nicely worked. Sowing may be made in the open ground from April to middle of August, every 2 or 3 weeks

Big Boston-Big, compact, tender, cream white heads. A very popular variety for Market Gardeners. It heads well in the open ground during cool weather in Spring and Fall and is grown very extensively in the South for shipping North during the Winter. It is also a fine forcing variety for coldframes during the Winter months. The quality is excellent. Pkt., 5c; oz., 25c; 1/4 lb., ite; 1 lb., \$2.00; parcel post paid.

Black Seeded Simpson-One of the best, either for forcing under glass or for open ground culture. It forms large, thin, loose leaves of light green color, very tender, crisp and of fine quality. A fine sort for Summer, as it withstands the heat; also for the home garden. Pkt., 5c; oz., 25c; $1 / 4$ lb., 60c; 1 lb., \$1.i5, parcel post paid.

California Cream Butter-Also called Royal Summer Cabbage. Dark green, round thick leaves forming a very solid round head which stands a long time without running to seed. Outer leaves spotted brown, inner ones blanched to a rich yellow. Excedingly rich

\section{Bonded Brand}

Culture-For summer sow as soon as you can in the spring, in drills 1 foot apart, 1 inch deep, and every two weeks for a succession. For Winter and early spring, sow in late August and September and protect with straw during severe weather. The ground for spinach cannot be too rich. One pkt. sows about 20 feet of drill; one oz., 100 feet; eight to ten lbs. per acre.

Long Standing-One of the best for Summer, as it is slow to turn to seed. Also sown in the Fall, but should have protection in winter. Leaves are large, thick and crimpled. Pkt., 5c; oz., 10c; $1 / \frac{1}{4}$ lb., 20c; lb., 50c; 5 lbs. (a) $40 \mathrm{c}$.

\section{Bonded Brand}

Culture-Sow in rows about a foot apart and thin to six inches apart in the row.

Southern Giant Curled-The leaves are twice the size of the ordinary White Mustard and the flavor is sweet and pungent. Highly esteemed for salads, particularly in the South. Pkt., 10c; oz., 15c; $1 / 4$ lb., 40c; lb., \$1.10.

Ostrich Plume-The leaves are long, ruffled and curled like an ostrich plume, and for this reason the plant is very ornamental. It is especially good as a salad and is equal to spinach for greens. Pkt., 10c; oz., 15c; $1 / 4 \mathrm{lb}$. 40e; lb., \$1.10.

Chinese-This is a very hardy variety. The eaves are large, thick, and somewhat crimped

\section{Bonded Brand LETTUCE SEED}

buttery, sweet and nutty in fiavor. Pkt., 5c; oz., 25e; 1/4 lb., 60c; 1 lb., \$1.75; parcel post paid

Early Curled Simpson-Makes a curly loose head: crisp and tender. Pkt., 5̃c; oz., 25c 4 lb., 60c; 1 lb., \$1.75; parcel post paid.

Improved Hanson-The most reliable header for home garden. On all markets-a well known, highly approved lettuce. Globe shaped, large, well formed, firm head of broad leaves so compact that the inner ones are blanched almost white. The outside leaves are glossy green and handsome, the inside ones are very tender and deliciously sweet, and all are beautifully crinkled and curled. For midsummer planting outdoors, this sort is exceedingly popular, for it has superior qualities for resisting drought and heat. Pkt., 5e; oz. 25e; $1 / 4$ lb., 60c; 1 lb., \$1.75; parcel post paid.

New lceberg-Prize Winner, Hard Header, Good Shipper, Quick growing and of exquisite flavor. Tlie large curly leaves which cover the outside of the solid head are of bright light green, with a slight reddish tinge on tlie edges. Pkt., 5̃c; oz., 35e; 1/4 lb., 80e; 1 lb., \$2.50; parcel post paid.

May King - A very. early heading variety. This is among the finest heading sorts. The outer leaves are green, just tinged with brown; they fold close, permitting close planting in frames-tender yellow heart. Pkt

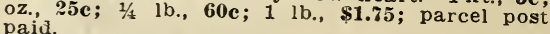

Wonderful or New York-The big Money Maker. The Standard Summer Main Crop Hot Weather Head Lettuce furnishes fine, crisp lettuce during the hot summer months. This is one of the largest varieties grown, producing heads more than 15 inches in diameter and weighing more than 2 pounds each. The outer color is rich dark green, but the heart blanches beautifully and is crisp, tender and delicious. It is reliable, a sure header, and is slow to go to seed. Pkt., 5c; oz., 25e: lb., 70c; 1 lb., \$2.25; parcel post paid.

Prizehead-Very popular, large, loose heading sort. Leaves finely crumpled and fringed, outer ones shaded brown; very crisp, sweet and tender. Pkt.. 5c; oz., 25c; $1 / 41$ lb., 60c;

\section{Spinach Seed}

Bloomsdale, or Savoy-Another hardy Winter variety. Leaves, numerous, curled, blistered and succulent. Glossy dark green color Sow in early Spring and use before hot weather, or in Fall or Winter use. The most largely grown variety. Pkt., 5c; oz., 10c: $1 / 4$ lb., 20c; 1b., 50c; 5 ibs., @40c.

New Zealand-One single plant will grow to dimensions of six inclies across, producing an abundance of thick, fieshy, juicy stems and leaves. The flavor is fine and it does well. Every market gardener should grow a crop. Pkt., 10c; oz., 15c; $1 / 4$ lb., 30c; lb., 80c.

\section{Mustard Seed}

at the edges. Pkt., 10c; oz., 15c; $1 / 4$ lb., $40 \mathrm{c}$; lb., \$1.10.

\section{BONDED BRAND KALE SEED}

Dwarf Curled Siberian-A very hardy and vigorous growing variety of spreading habit, its foliage having a distinct bluish tinge. This is the most popular variety grown, especially in the South. Pkt., 10c; 1 oz., 15e; $1 / 4$ lb., 25c; 1 lb., 60c; postpaid.

Tali Green Curled Scotch-The plant of this variety grows 3 to 4 feet high, bearing long plume-like light green leaves, which are deeply cut, also finely curled at edges. Pkt., 10c; 1 oz., 15e; $1 / 4$ lb., 40c; 1 lb., \$1.00; postpaid. 


\section{Bonded Brand Beets}

\section{Beats Any You Ever Tried!}

\section{Table Varieties}

Culture-For tert early crop sow in hotbeds in January and February and transplant. Sow outside in drills from March to July, as desired, for medium, early or late crop. Drils ? to 3 feet apart. Lze a light, clean, free deep soil. One ounce will sotw 50 feet of drill.

Crosby's Improted Egyptian-The color is tright $\mathrm{r} \neq \mathbb{d}$ with bright $\mathrm{v} \in \mathrm{rmillion}-\mathrm{red}$ \&esh, rery sweet and tender. It has the adrantage of being fit for use earlier than most beets, as it takes on its turnip shape at a rery early stage of its growth. Plkt., 5e; oz., $10 \mathrm{c} ; 1 / 4 \mathrm{lb}$., 25e; 1 1b., ise; parcel post paid.

Detroit Dark Blood-Here is a beet rou mill like, whether you grow for home use or market Almost globe shaped with small topg and tap root, very smooth and of cark bloodred color without light rings. \& good beet for both early and late planting. The quality is fine: for canning it has no superior. Pht., $5 \mathrm{c}$; 0z.. 10c; 2; 1b., 25e; 1 lb., $75 \mathrm{c}$; parcel post paid.

Early Blood Turnip-It is distinctly a beet that will please you A beet that has the approzal of the most discriminating gardenerg everywhere. The roots are medium sized, round. of dark red color and fine flator. Matures in about 45 days. Pkt. 5e; 0z., 10e; is 16., 25c; 1 lb., ise; parcel post paid.

Eelipse- in eariy beet used for burching. The tops are small. The roots are bright deep red, smooth, round or slightly top shaped, with a small tap and small collar. The flesh is bright red zoned with pinkish white, vers sweet, crisp and tender. Pki, $5 \mathrm{ci}$ oz.. 10c; 14 1b., $25 \mathrm{e}$; 1 lb., $75 \mathrm{c}$; parcel post paid.

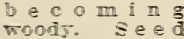
should be somn Juis ist to 15 th for $a$ win $\tau$ er crop, as it is a rather $s 10$ wrower. Plit. 5c: oz, 10c: is io. $30 \mathrm{c}: 1 \mathrm{lb}, 85 \mathrm{c}$;

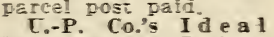
Blood Tarnip-Earliest of ail: the best extra early red turnip beet, not only for market gardeners, but for canting. ard especiallt for the home garden. Iop small, upright growing, so that the rows may be ciose together. Poot giotular or oroid and vers smooth. Color of skir dark blood red; flesh deep rermillion $r \in d$ zoned with a darker shade. Vers crisp. tender and sweet and remaining so for a long time. Plt, 10e; oz. 90e; 1 , lb, 50c; 1 lb. 81.25 ; parcel pos: Daid

Long Dark Blood-A standard late rariety, keeping well through the winter. The root is long and skin smcoth. Flesh very dark red, sweet and tender. The roots are thick shouldered, grow largely under ground, ars, when mature, about 2 inches in diameter and 10 inches long. Ther are ready for the table in about 50 dass. Pkt, 5e: oz. 10e: Half Long Blood-A distinct rariety used bushel. The root is twice as long as thick, fiesh rich äark red and of excellent quality, which it retains throughout the winter, never

\section{For Stock Feeding}

Culture-Sow $C$ pounds to the acre in March or April, in rows three feet apart, and thin to rine inches in the row. Cultivate frequentlr with horse toois

Golden Tankard Mangel Beet-Small top, smooth, rich skin, broad shoulders, rery solid fleshed. golden stemmed, heavy producer. Pkt., 5e; oz., 10c; 1; 10., $95 \mathrm{e}$; 1 ib., $60 \mathrm{c}$; parcel post paid.

Giant Feeding. Sugar Beet-A large growing sort, and used for ieeding sicck. Plkt, je; oz., 10e; 24 lo., 9.5c; 1 lb., E0e: parcel post paid

Klein. Wanzleben Sugar Beet-Extensively grown for making sugar: the aterage rield is from 15 to 20 tons per acre with about is per cent sugar. Pkt, 5e; oz., 10c; is 1b., 25c; 1 1b.,60c; parcel post paid.

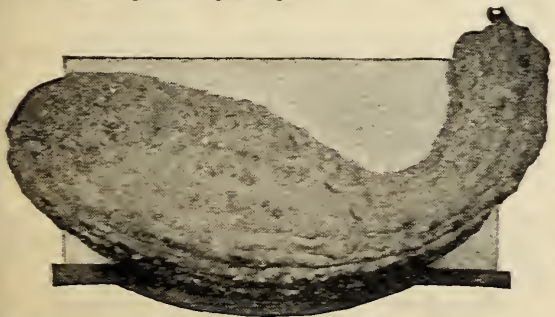

Mammoth Summer Crookneck-O=e of the summer Squashes. It is twice as large as the ordinary summer Crookneck, highls attractive, several days earlier. This combination of earliness and size makes it a most desirable variety for the market gardener as well as for private use. Pkt., 10c; oz., 15c; 1; lb., $40 \mathrm{c} ; 1 \mathrm{~b} ., \mathbf{\$ 1 . 3 0}$.

\section{Bonded Brand Squash}

The summer or bush squashes should be planted in hills from fout to fre feet apart and the winter or vining kinds in hills from to 10 feet apart. Squashes are heary feaders and it is iherefore beneficial to put two a: three forksful of manure in each hill

Plant from 10 to 12 seeds in each hill bu when the plants are of fair size thin then down to three plarts to the hill. One ource will plant about 40 hills of the small sorts and about 20 of the large sorts. 4 to 5 pounds :0 the acre

BLSH OR STMMER VARIETIES

Giant Summer Crookneck-A small crooknecked summer squash: shin bright rellow, corered with wart? excrescences. Ter early, productive, and of excellent faror. Pkt. 10c; oz, 15c; $1416 . .40 \mathrm{c} ; 1 \mathrm{~b} ., \$ 1.95$.

Mammoth White Bush-The fruit is a beautiful clear white wax instead of the Yeilowish-white so often seen in the old stock, and is much larger. Pht, 10e; oz., 15e; ? 1b., $30 \mathrm{c} ; 13$., $\$ 1.10$. 


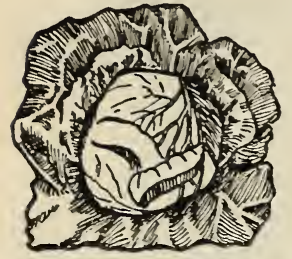

\section{Bonded Brand Cabbage Seeds}

CULTURE-Cabbage being of the gross feeder sort, well repays heary manuring and high culture. The plants are started in frame or sled bed, and afterwards transplanted. Seed for early cabbage may be started in early Autumn in a cold frame or in early Spring in a hot bed. For main crop, Summer and Autumn Cabbage, the seed should be sown in a rich border in the open air in May or June. Sow shallow. Set plants $1 \frac{1 / 2}{2}$ to 3 feet apart.

All-Head Early-Early, large, flat, solidheaded. Pkt., 5e; oz., 20c; 1/1 lb., 60c; 1 lb., \$1.75; parcel post paid.

All Seasons-One of the largest and a thoroughly satisfactory second earlies. This is a first class sort both for early and late planting. Pkt., 5e; oz., 20e; $1 / 4$ lb., 60e; 1 lb., \$1.ซ5; parcel post paid.

Charleston or Large-type Wakefield-The cne big advantage of Charleston is the greater size, where large-sized cabbages are wanted either for market or private use. It is fully one-third larger than the Jersey Wakefield and therefore more popular. Heads are solid, pointed and is a heavy yielder. Pkt., 5e; oz. 25e; $1 / 4$ lb., F0c; 1 lb., \$2.25; parcel post paid.

Copenhagen Market-One of the earliest round head or flat cabbages. On account of extreme earliness, being almost as quick maturing as Charleston Wakefield, it is destined to become one of the leading sorts. Pkt., 5c; oz. 25e; 1/4 lb., 70c; 1 lb., \$2.25; parcel post paid.

Chinese or Celery Cabbage-PE-TSAI-Has a mild cabbage flavor, very delicate and very fine salad.

The culture is the same as for Cabbage. The seed should be sown for fall crop in June, July. to September, half inch deep in the row and rows about 24 inches apart. When the plant has grown up to 5 or 6 inches in height thin to 10 inches apart. Pkt., 5e; oz., 30e; is lo., 90e; 1 lb., \$2.50; parcel post paid.

Danish Winter Ball Head-A medium-sized, very solid heading sort, which will remain in good condition longer than most varieties. Plant compact and very hardy. Pkt., 5e; oz., 20c; $1 / 4$ Ib., 60c; 1 lb., \$1.75; parcel post paid.

Large Drumhead Savoy-The best and largest heading of the Savoy. Few people seem to know the delicious flavor of Savoy Cabbage. It is far superior to the flat-leaved sorts, and as tender as cauliflower after frost. Pkt., 5c; oz., 20c; 1/4 lb., 60c; 1 lb., \$1.75; parcel post paid.

Early Jersey Wakefield-In size, medium; in shape, pyramidal with pointed peak. Its uncommonly fine heading qualities, together with its fitness for wintering in cold frames, pleases the most critical gardeners. Pkt., 5e; oz., 25e; $1 / 4$ lb., 70c; 1 lb., \$2.25; parcel post paid.

Early Suring-Probably the earliest of flatheaded varieties. A profitable cabbage to grow, as it heads early, has a short stem forming a round somewhat flat head quickly. Pkt., 5c; oz., 25e; $1 / 4$ lb., 70e; 1 lb., \$2.25; parcel post paid.

Early Drum Head-One of the best second early varieties; large, deep heads; solid. Pkt. Ec; oz., 20c; 1/4 lb., 60c; 1 lb., \$1.75; parcel post paid.
Early Winnigstadt-A popular sort for the garden, as it remains in good condition for a long time. Heads pointed, medium size, hard and of a dark green color. Pkt., 5e; oz., 20c; $1 / 4$ lb., 60c; 1 lb., $\$ 1.75$; parcel post paid.

Large Late Drumhead-Rounder than Flat Dutch, good, large heads. Pkt., 5e; oz., 20c: 1/4 lb., 60e; 1 lb., \$1.75; parcel post paid.

Mammoth Red Rock-By far the best, largest and hardest heading red cabbage in cultivation: very uniform in size, weight, solidity and deep red color. Pkt., 10c; oz., 35c; 1/4 lb., \$1.00; 1 lb., \$3.00; parcel post paid.

Late Flat Dutch-Sure header, producing large, solid heads, flat on top, of low growing habit. Pkt., 5e; oz., 20e; $1 / 4$ lb., 60e; 1 lb., \$1.75; parcel post paid.

Succession-Matures in about 110 days. Heads round, slightly flattened. Pkt., 5e; oz., 25e; $1 / 4$ lb., ;0e; 1 lb., \$2.00; parcel post paid.

Early Dwarf Flat Duteh-It is a large cropper and a dependable header. A short stemmed variety. Belongs to the second earlies. Matures in about 110 days. Pkt., 5e; oz., 25e; 1/4 lb., 70c; 1 lb., \$2.25; parcel post paid.

Eariy Summer-Solid round head; comes in just after Wakefield. Pkt., 5e; oz., 20c; $1 / 4$ Ib., 60e; 1 lb., \$1.75; parcel post paid.

\section{Bonded Brand Salsify Seed}

Culture-This plant is used as a substitute for oysters. Sow early in the Spring on rather light, fertile ground, in drills 18 inches apart; thin the plants to 1 or $1 \frac{1}{2}$ inches in the row. Light freezing greatly benefits the flavor. One pkt. for about 25 feet of row; one to 75 feet.

Mammoth Sandwich Island-The best va. riety. Pkt., 10c; 0z., 25e; $1 / 4$ lb., 70c; lb. $\$ 2.50$.

Fine Curled (Pepper Grass)-Pkt., 5c; oz., 15e; $1 / 4$ lb., 50c.

Water Cress-Must be grown by wateralong the banks of ponds or streams. Seed should be started in bed and transplanted to where wanted. Plit., 10e.

\section{Bonded Brand Leek Seed}

London Flag-Pkt., 5c; oz., 20e; $1 / 4 \mathrm{lb} ., 50 \mathrm{c}$; 1 lb., \$1.75; parcel post paid.

\section{Bonded Brand Endive Seed}

Green Curled-The hardiest variety; beautirully curled. Pkt., 5c; oz., 20c; $1 / 4$ lb., 50c; 1 lb., \$1.25; parcel post paid.

Broad Leared Batavia-(Escarolle)-Leaves long and broad, thick and succulent. One of the choicest salads. Pkt., 5e; oz., 25c; 1/6 lb., 60e; 1 lb., \$1.50; parcel post paid. 


\section{Bonded Brand Onion Seeds}

Culture-Sow in January or February in hotbeds. Transplant to 12-inch rows, 5 inches apart.

Prizetaker-Very large and solid; skin rich yellow; flesh pure white, sweet, mild, tender. Pkt., 10e; oz., 40c; 1/4 Ib., $\$ 1.25$; 1 lb., \$4.50; parcel post paid.

Large Red Wethersfield-Medium early; skin is purplish red; a general favorite. Pkt., 10c; oz., 35e; 1/4 1b., \$1.15; 1 lb., $\$ 4.00$; parcel post paid.

White Crystal Wax Bermuda-This is without a doubt the world's most attractive Onion. Pkt., 10e; oz., 50e; 1/4 1b., \$1.75; 1 lb., \$5.00; parcel post paid.

Large Red Globe-Grows to good size; rich red color; a fine keeper. Pkt., 10e; oz., 45e; 1/4 lb., \$1.40; 1 lb., \$4.75; parcel post paid.

\section{Bonded Brand Pepper Seeds}

Peppers should be started in hotbeds, in February or March, and not planted outside until the soil is warm and there is no danger of frost. Set the plants in rows 2 feet apart and 18 inches in the row. Hoe often and keep the weeds down.

Bell or Bullnose-This variety is sometimes used for stuffing, but it is really one of the hot peppers. Pkt., Jc; oz., 40c; 1/4 lb., \$1.25; parcel post paid.

Chinese Giant-One of the very best and largest Mlango peppers, glossy red, mild flaver. Pkt., 10c; oz., 50c; 1/4 lb., \$1.50; postpaid.

Crimsen Giant-Very large sweet variety, matures early. The flesh is thick and sweet. Pkt., 5e; oz., 40c; $1 / 1$ lb., \$1.25; postpaid.

Long Red Cayenne-This fruit is a brilliant coral red, conical, 2 to 3 inches long: Pkt., 10c; oz., 50e; 1/4 lb., \$1.00; 1 lb., $\mathbf{\$ 3 . 2 5}$; postpaid.

Pimento-Mild thick heavy flesh and has a delicate flavor. Pkt., 10c; $1 / 2$ z., 30c; oz., 50c; $1 / 4$ lb., \$1.80; postpaid.

Red Chili-The fruit is bright red, very hot and fiery. Pkt., 10c; $1 / 2$ oz., 25c; oz., 45e; postpaid.

Royal King-A fine variety, very large and attractive, fruit 4 and 5 inches long, bright red. Pkt., 10e; $1 / 2$ oz., 25e; oz., 4be; postpaid.

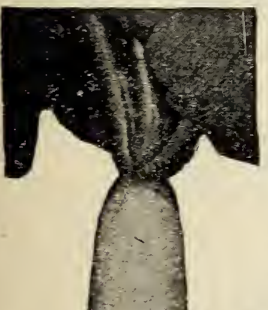

\section{Bonded Brand Radish Seed}

\section{Imported}

Culture-To be tender and crisp, radishes must be grown quickly, and this requires rich soil and moisture. Begin as early as possible in tire spring and sow at intervals of and winter sow in August and September. One ounce sows 50 feet in drills.

Early Scarlet Turnip-A very early, small, round radish: entire radish is of a rich scarlet color. Pkt., 5e; oz., 10e; 1/4 lb., 30e; lb., т0c; parcel post paid.

Early Scarlet Globe-A very distinct shape, brilliant red color, short leaved, crisp and white, of excellent flavor. Pkt., 5c; oz., 15e; $1 / 4$ lb., 35c; lb., 85c; parcel post paia.

Early Long Searlet Short TepEarly, very short top, splendid shape and color. PKt., 5es oz. 10c; $1 / 1$ lb., 30c; lb., 70c; parcel post paid.

French Breakfast - A very popular scarlet, tip p d with white, and small in Freneh variety of very rapid growth, color, size. Pkt., 5e; oz., 10e; 1/4 lb., 30c; lb., 75e; parcel post paid.

Cooper's Sparkler-This radish is an inproved type of the Scar- let Turnip White Tip and is superior to the original. The top half is beautiful scarlet, the bottom half clear white. Pkt., 5e; oz., 15c; $1 / 4$ lb., 35c; 1b., 85c; parcel post paid.

Ieicle-Long, s 1 e $\mathrm{n}$ d e r, pure white, the earliest and finest long, white radish. Pkt., 5e; oz., 10e; $1 / 1$ lb., 30c; lb., 75e; parcel post paid.

Long Black Spanish-Ore of the latest and hardiest long winter use. Roots rather long, thick, almost blaek, with white flesh. Pkt., 5c; oz., 10c; 1/4 1b., 30e; 1 lb., 75c; parcel post paid.

China Rose Winter-One of the very best for fall and winter use, bright rose color, flesh white and firm, superior quality. Pkt., 5c; oz., 15e; $1 / 4$ lb., 35c; 1 lb., 85e; pareel post paid. 


\section{Bonded Brand Turnip Seeds}

Culture-Spring sowing should be put in early so that they will attain a good size before hot weather. For the regular crop, sow the early sorts in July or August, the later sorts during August, and the salad varieties during August and September. Sow either broadcast or in drills 2 feet apart. thinning out to 6 inches and roll the ground after sowing. Rutabagas should be sown in July and early in August, and earthed up as they grow. New ground makes the best turnips, or, if sown in your garden, first mix a good supply of phosphate with the ground, then sow your seed. Cover the seed about $1 / 2$ inch. Sow $1 \frac{1 / 2}{2}$ pounds to the acre in drills, 2 pounds broadcast.

Mammoth Purple Top White Globe-One of handsomest and most salable turnips. For home or market it is unsurpassed. It is a large, rapid growing sort, being ready for the table or market in about 65 days, witi globular shaped roots. Flesh pure white, and the best flavored of all turnips, raw or cooked. The skin is white, with a purple top. Pkt. כe; oz., 10c; $1 / 4$ lb., 20c; 1 lb., 50c; 5 lbs., \$2.25; parcel post paid.

Extra Early White Milan-The earliest turnip. Tops very small, distinctiy strapleaved and growing very erect. Pkt., 5c; oz. 10c; $1 / 4$ lb., 25c; 1 lb., 75e; parcel post paid.

Extra Early Purple Top Milan-A white variety, purple top and strap-leaf. This, with the White Milan, is the earliest of all turnips. Pkt., 5c; oz., 10c; $1 / 4$ lb.,.25c; 1 lb., 75c; parcel post paid.

Extra Early White Egg-A quick growing, egg shaped, pure white variety. Very sweet, firm and mild. Pkt., 5c; oz., 10c; $1 / 4$ ih., 20c; 1 lb., 50c; 5 lbs., \$2.25; parcel post paid.

Long White Cow Horn-A long white turnip, 12 to 15 inches in length, $2 \frac{1}{2}$ inches in diameter alld growing well above the ground. Of rapid growth, producing large, heavy roots in 75 days. One of the best and sweetest for home use or for stock feeding and excellent to plow under as a green fertilizer. Pkt., 5c; oz., 10c; 1/4 lb., 20e; 1 lb., 50c; 5 lbs., \$2.25; parcel post paid.

Large Amber Globe-Of large size, globe shaped, solid yellow flesh; green top. Fine for table and stock. Pkt.. 5e; oz., 10e; $1 / 4$ lb., 20c; 1 lb., 50c; 5 lbs., \$2.25; parcel post paid.

Large White Globe-A popular variety. Makes large, round white roots, flesh white, solid, sweet and fine grained, maturing in about 75 days. Excellent for table or stock: also quite largely used for spring salad. Pkt., 5e; oz., 10c; $1 / 4$ lb., 20c; 1 lb., 50e; 5 lbs., \$2.25; parcel post paid.

\section{Bonded Brand Sweet Corn}

\section{EARIY GARDEN VARIETIES}

Golden Bantam-Early Sweet Corn, with yellow kernels. Very sweet and delicious; tender and of excellent quality. One of the hest early varieties. Pkt., 10c; lb., 25c; 2 lbs. 45c; post paid.

Country Gentleman-The most delicious of all Sweet Corns, and also one of the most productive sort.. Pkt., 10c; lb., 25c; 2 lbs. 45̃c; post paic.

stowell's Evergreen-The best late sweet corn in every way, being large eared, hardy and productive. Pkt., 10c; lb., 20c; 2 lbs., 35 e; post paid.

Adan's Extra Early-The hardiest and earliest variety. It is not a Sweet Corn, but produces ears well filled with tender white grains. Pkt., 10c; lb., 20c; 2 lbs., 35c; post paid.

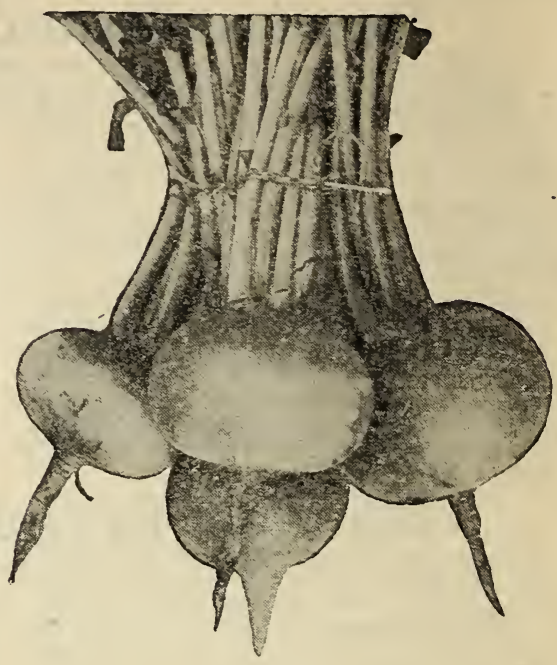

Adams' Early Large-One of our leading varieties. Ears are large and handsome. Pkt., 10c; 1b., 20c; 2 lbs., 35c; postpaid.

Hickory King, Iowa Silvermine and White Pearl are all good to plant for roasting ears. Pkt., 10c; lb., 20c; 2 lbs., 35c; post paid.

Howling Mob-A big-eared medium early corn with the sweet flavor of the late varieties; ears 7 to 9 inches long; usually two pearly white ears to the stalk; the shuck extends well over the tip and protects it from the green worm so destructive to early sweet corns. $1 / 4$ lb. pkt., 12c; $1 / 2$ lb., 20c; lb., 40c; 5 ibs.@35c; post paid.

\section{Rutabaga Seed}

Culture-Sow in drills or broadcast in June, July and August.

Improved Purple Top Yellow-The perfect Rutabaga, of symmetrical shape and firm flesh. The finest and most profitable of all yellow, purple top Rutabagas, being the hardiest, heaviest, best shaped and most productive. The roots are better keepers than most sorts. The flesh is of a beautiful yellow color of the choicest quality, full of nourishment. Excellent for table use and stock feeding. Matures in 95 days. Pkt., 5c; oz., 10c; $1 / 4$ lb., 20c; 1 lb., 50c; 5 lbs., \$2.25; parcel post paid.

\section{Cauliflower Seed}

Early Nanish Snowball-A sure header, large, solid, perfect white and good quality. Pkt., 10c; oz., \$1.25; $1 / 4$ lb., \$3.50; parcel post prepaid.

Early Dwarf Erfwrt-Noted for extreme reliability in heading-heads 8 to 10 inches. Can be marketed early in July. Pkt., 25c; $1 / 4$ oz., $85 \mathrm{c}$; oz., $\$ 3.00 ; 2$ oz., $\$ 5.00$.

\section{Corn Salad Seed}

Large Round Leaved-The well-known variety. Ready to use in 4 to 5 weeks. Pkt., 5c; oz., 15c; $1 / 4$ lb., 30c; 1 lb., 75c; parcel post paid. 


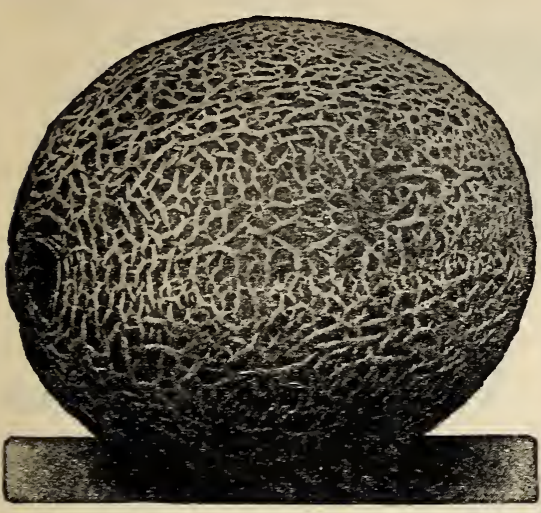

Acme, or Baltimore-One of the best of cantaloupes for main crop. The flesh is thick, of a beautiful deep rich green. Pkt., 5e; oz., 15e; 1/4 lb., 35e; 1 lb., \$1.00; parcel post paid.

Banana-Long, shaped like a banana; has a most delicious flavor. Pkt., 5e; oz., 20c; $1 / 4$ lb., 40c; 1 lb., \$1.25; parcel post paid.

Burpee's Early Netted Gem-About two weeks earlier than other varieties, very prolific and hardy. Has phenomenally thick green flesh with golden yellow lining, small seed pockets, beautifully netted, slightly ribbed, the grandest table and market Cantaloupe ever produced. Color, light green. Pkt., 5c; oz., 15e; $1 / 4$ lb., 40c; 1 lb., \$1.25; parcel post paid.

Honey Dew Melon-A splendid new variety; rind dull white when ripe. The flesh is a rich green, very sweet and delicious fiavor. The average size is about six inches in diameter and tney weigh five to six pounds. The skill is smooth with little netting. Pkt., 5e; oz., 20c; $1 / 4$ lb., 50c; 1 lb., \$1.25; parcel post paid.

Hearts of Gold - Extremely Thick, Sweet Orange Flesh. An ideal basket and crate melon of medium size, round, heavily netted, flesh very thick, of rich orange color, handsome appearance, and of the sweetest flavor. Average size of melon 6 to 8 inches in diameter. Matures in 75 days. The seed cavity is small and the rind is very tough, making it a good shipper; its vine is a vigorous grower and $a \bullet h e a v y$ cropper. A very convenient sized melon for the table and for packing in shipment. Pkt., כe; oz., 15c; $1 / 4$ lb., 40e; 1 lb., \$1.25; parcel post paid.

Rocky Ford-One of the most popular. Just right size for restaurant and hotei service; flesh is green, thick, and lusciously sweet. It is netted and ribbed and ripens early. Pkt., 5e; oz., 15e; 1/4 lb., 35e; 1 lb., \$1.00.

Pink Meat Rocky Ford-This is an early melon of the solid netted type that is so desirable. Very small seed cavity, with thick, luscious flesh of genuine salmon tint shading to green near the

\section{Bonded} Brand

\section{Cantaloupes}

CULTURE-Plant in hills 5 feet apart in light, rich soil, well manured; 10 seeds to hill; thin to 4 plants. Cultivate well. Pinch off ends of vine as they begin to blossom, which will increase the yield. One ounce to 60 hills. For borers or worms spray as soon as blossoms appear with Bordo Arsenate and add Blackleaf 40 .

rind. A splendid keeper that stands shipping and always arrives in the best possible condition. It has been successful in the East, in the West, and in the South. It is a prolific yielder and has been pronounced by every one who has used it as the ultimate in salmon-fleshed melons. Pkt., 5c; oz., 15e; 1/4 lb., 40c; 1 lb., \$1.25.

Early Green Nutmeg-An early variety of medium to a small size; nutmeg in shape and thickly netted. Pkt., 5c; oz., 15c; $1 / 4$ lb., 35c; 1 lb., \$1.00; parcel post paid.

Tip Top-Nearly round, deeply ribbed, moderately netted; flesh is bright salmon, thick and of good flavor. Pkt., 5e; oz., 15c; $1 / 4$ lb., 40e; 1 lb., \$1.25; parcel post paid.

One ounce will plant 100 hills.

\section{Bonded Brand Egg Plant}

CCLTURE-Sow in February or March. When 2 inches high transplant in May to 3 -foot rows in deep, rich loam. One ounce of seed will produce 1,000 plants.

Black Beauty-This is the earliest and best of all large fruited Egg Plants. Fruits are thick and of the most attractive form. The skin is a rich, lustrous purplish black. Pkt., 5c; oz., 40c; 1/4 lb., \$1.20; 1 lb., \$4.00; parcel post paid.

New York Improved Purple-The old standard variety. Pkt., 5e; oz., 40e; 1/4 lb., \$1.20; 1 Ib., \$4.00; parcel post paid.

\section{Bonded Brand Okra or Gumbo}

CULTURE-Sow late in the Spring, after the ground has become warm, in drills 3 feet apart, and, when the plants are three inches high thin out from 10 to 12 inches. They should be well manured.

Early Dwarf Prolific-Short podded and productive. Pkt., 10e; oz., 15e; $1 / 4$ lb., 25c; lb., 60c.

White Velvet-They are of attractive appearance and superior flavor and tenderness. The plants are comparatively dwarf and of compact branching growth; the pods are of extra large size and produced in great abundance. Pkt., 10c; oz., 15c: $1 / 1$ Ib., 25e; Ib., 60c. 
For prices ou Parsley, Sage, Dill, Hamburg: Turnip Rooted and other seeds and plants not listed, write us:

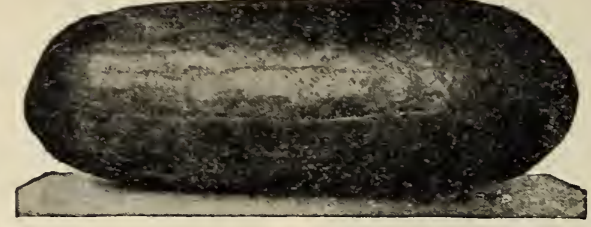

For prices on Parsley, Sage, Dill, Hamburs: Turnip Rooted and other seeds and plants not listed, write us:

\section{Bonded Brand Watermelons}

CULTURE-One ounce to forty hills; three or four pounds to the acre. Drop in the middie of Spring, in hills six to eight feet apart, six to ten seeds, one inch deep, and thin to three best plants. Generally about the middle of April is the proper time to plant melons in this section.

Alabama Sweet-The flesh is bright red, fine grained, sweet and luscious. Pkt., 5x; oz., 10c; $1 / 1$ 1b., 25c; 1 lb., 75c; parcel post paid.

Black Diamond-Immense in size, and grows to average 70 to $90 \mathrm{lbs}$.; rich dark green, uniform, round to oval shape; flesh deep red, of fine quality. Pkt., 5e; oz., 10c; $1 / 4$ lb., 25c; 1 lb., 75c; parcel post paid.

Bradford-This excellent $\mathrm{s} h$ i p p i $\mathrm{n} \mathrm{g}$ melon is one of the leading sorts grown by Texas and other Southern Melon Growers' Associations and extensively individual growers. The rind is dark green marked with a still darker green mottled strip, and while thin it is very tough, making the melon a first-class shipiper. The flesh is bright red, fine grained, sweet and luscious, entirely stringless and very firm. The seeds are white, slightly tipped with brown, and are firmly set in small cavities near the rind. Pkt., 5e; oz., 10e; 1/4 1b., 30c; 1 lb., 85c; parcel post paid.

Florida Favorite-Oblong in shape, growing to a very large size; rind dark green, striped with lighter; highly prized on account of its delicious flavor; seed light color, Pkt., 5c; oz., 10c; 1/1 1b., 25e; 1 lb., 75e; parcel post paid.

Golden Honey-The flesh is bright, golden yellow, as sweet as sugar. Pkt., 5c; oz., 15e; $1 / 4$ lb., 35e; 1 lb., \$1.00; parcel post paid.

Halbert Honey-The melons average eighteen to twenty inches long and are full or bluntly rounded at both ends. The skin is a dark glossy green. The flesh is a beautiful crimson, the rich coloring and luscious quality extending to the thin rind. Pkt., 5e; oz., 10c; $1 / 4$ lb., 25e; 1 lb., 75e; parcel post paid.

Irish Grey-(New). This new melon has been offered for a few seasons only, and is already becoming popular. The vine is very vigorous and holds up well, producing fruit until late summer. The rind is greenish grey in color, thin but very tough, hence a good shipper. Flesh is beautiful red and free from stringi- ness. Shape and size similar to Tom Watson. Well adapted for either market or home use. Pkt., 5c; oz., 10c; 1/4 lb., 30c; 1 lb., S5e; parcel post paid.

IRleckley's Sweet-A great melon for home and nearby markets. This splendid Watermelon has certainly become very popular wherever it has been thoroughly tested. It is of superb luscious flavor. Flesh is bright scarlet, with solid heart, deliciously crisp, sugary and splendid in every way. The melons average from 18 to 20 inches in length by 10 to 12 inches in diameter; of handsome appearance; ripen early, and are most desirable for the home-garden. Pkt., 5e; oz., 10e; 1/4 lb., 25c: 1 1b., 75e: parcel post paid.

New Wonder-Introduced in the South last year, resembles Kleckley Sweets, but grows to a larger size; the bright red flesh is deliciously sweet and melting. The introducer claims it is the melon of quality, the sweetest of them all. Pkt., 5c; oz., 15c; 1/4 Ib., 35c; 1 lb., $\$ 3.00 ;$ parcel post paid.

Red Seeded Citron-Fruit round and smooth. Is not eaten raw, but is used for making a very clear, transparent preserve of peculiarly fine flavor. Flesh white and solid. Pkt., 10c; oz., 20c; 1/4 lb., 40c; 1 lb., \$1.25; parcel post paid.

Southern Rattlesnake-A large striped variety of oblong shape; flesh scarlet and of superior quality. Pkt., 5e; oz., 10e; 1/4 1b., 25c; 1 lb., 75c; parcel post paid.

Thurmond Gray-A remarkably new delicious melon, a big money maker, and supreme satisfaction to all who grow it. The flesh is bright sparkling red, the flavor is deliciously sweet and satisfying. The vines are most vigorous and wilt resistant. Pkt., 5c; oz., 15e; 1/4 1b., 35e; 1 lb., \$1.00; parcel post paid.

Tom Watson-Long, green and very prolific. The melons are uniformly large, running from 30 pounds to 40 pounds. The flesh scarlet of extreme fineness and sweetness, entirely stringless, fairly melts in your mouth. Pkt., se; oz., 10e; 1/4 lb., 25e; 1 lb., 75e; parcel post paid. 


\section{Please Use This Order Blank - For Plants}

Union Plant Co.,

Date................192 .

Texarkana, Ark.

Enclosed find \$..... for which send the following as listed below to my address by .............. Name.

(Write very plainly)

Postoffice.

State...

R. F. D.

. Box

Street

Express Office

(If different from P. O.)

State When Wanted Shipped..

More order blanks will be sent upon request. Always write letters on a separate sheet from your order.

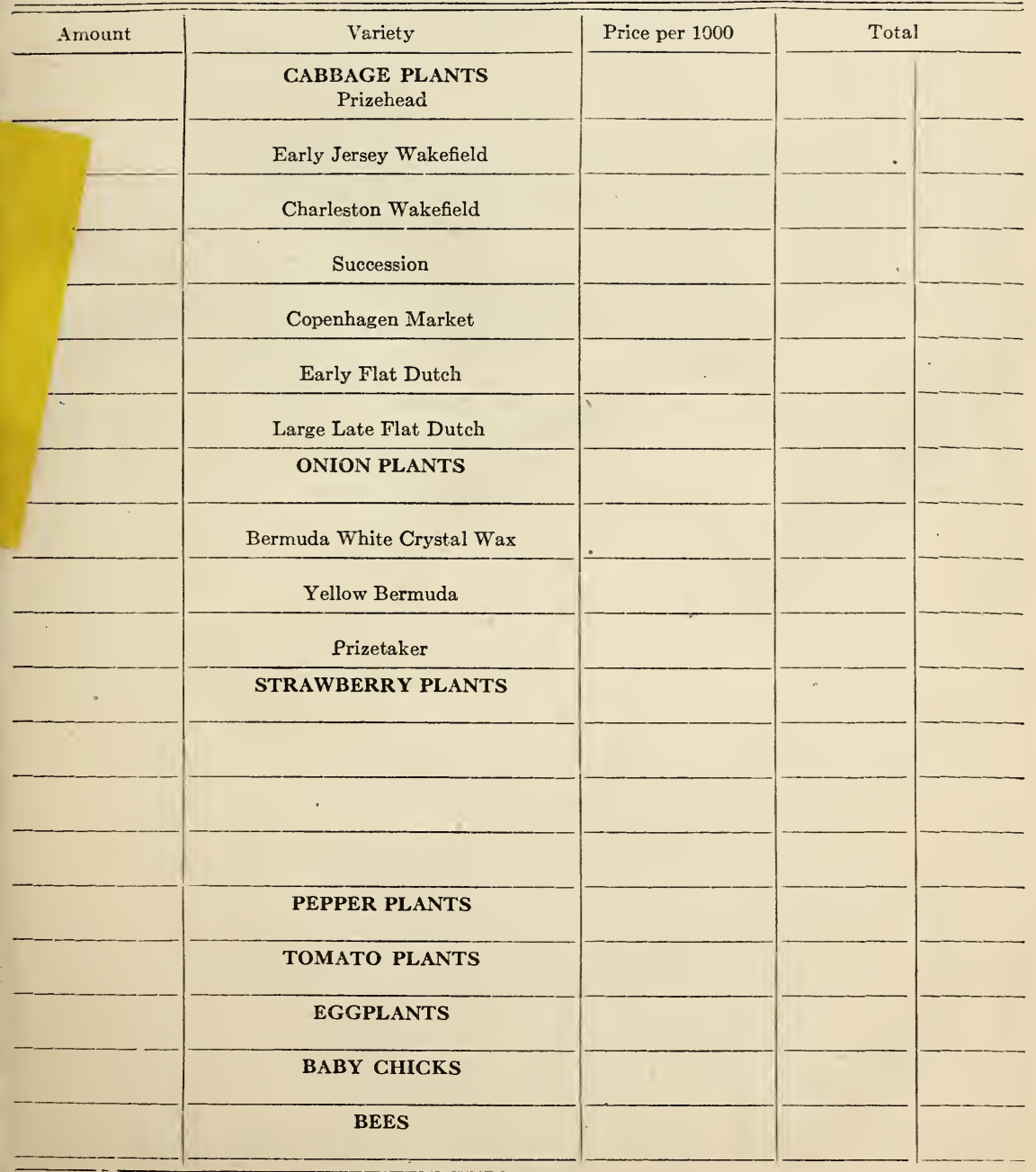




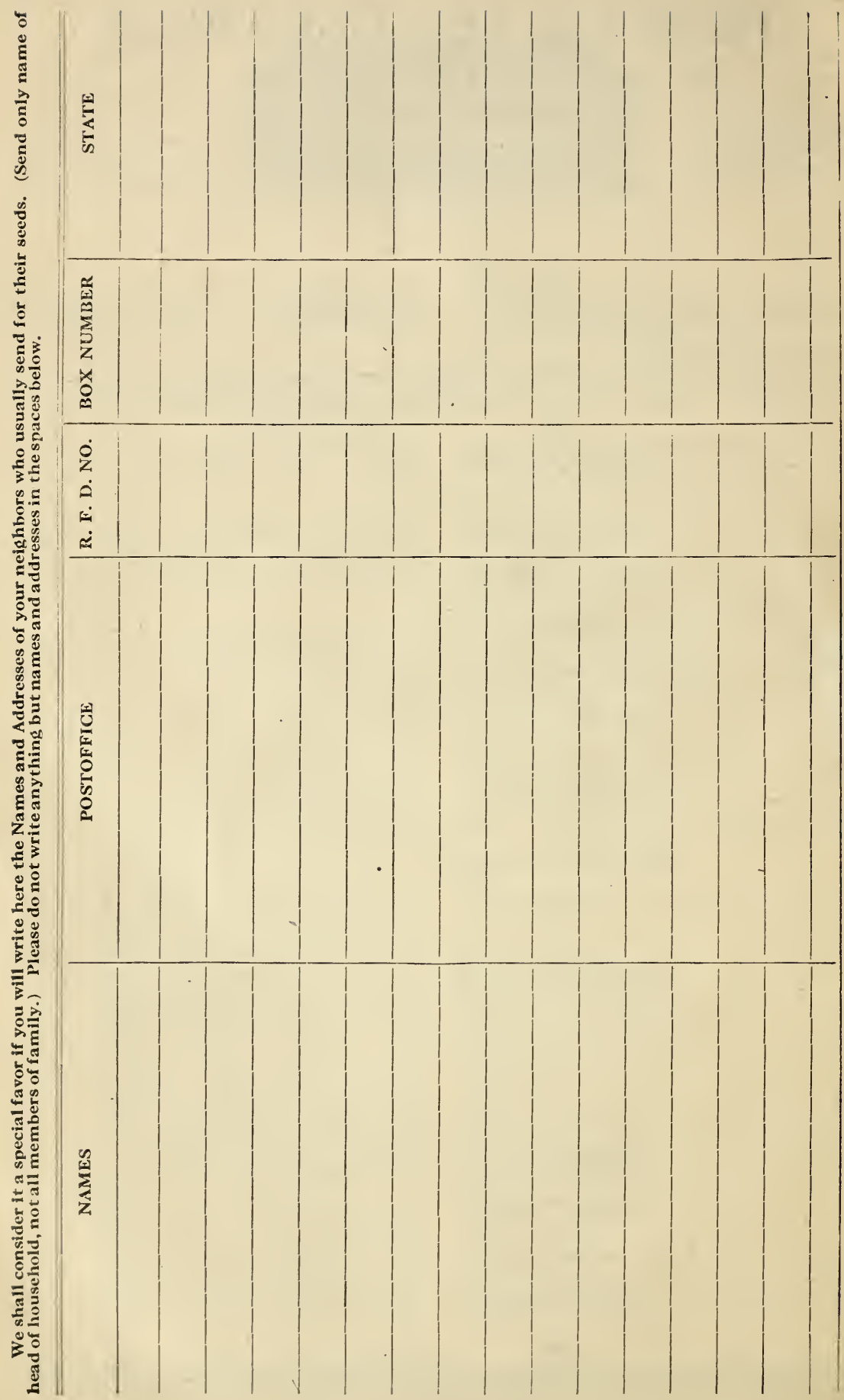


Please Use This Order Blank

Union Plant Co.

Texarkana, Ark.

Enclosed find $\$$...... for which send the following as listed below to my address by

Name.....

(Write very plainly)

Postoffice.

State....

R. F. D

Box

Street.

Express Office.

(If difierent from P. O.)

State When Wanted Shipped

More order blanks will be sent upon request. Always write letters on a separate sheet from your order.

We do not warrant in any way, exoress or implied, the contents or the description, purity, productiveness, or any other matter of any seeds, bulbs or plants, sold by us, and we will not be in any way responsible for the crop. If the purchaser does not accept these goods on the above terms, no sale is made thereof, and he must return them at once, and money will be refunded. Subject to the above conditions, we make this sale at the moderate prices we charge.

N. B. Examine seeds closely, test if desired, write us if anything is wrong and we will adjust.

Please Read. If we should be sold out on a variety, on your order, shall we substitute with a Please Read: variety equally as good quality as the variety ordered, or return your money? PLEASE MARK WITH AN X.

Substitute........... Return Money...........

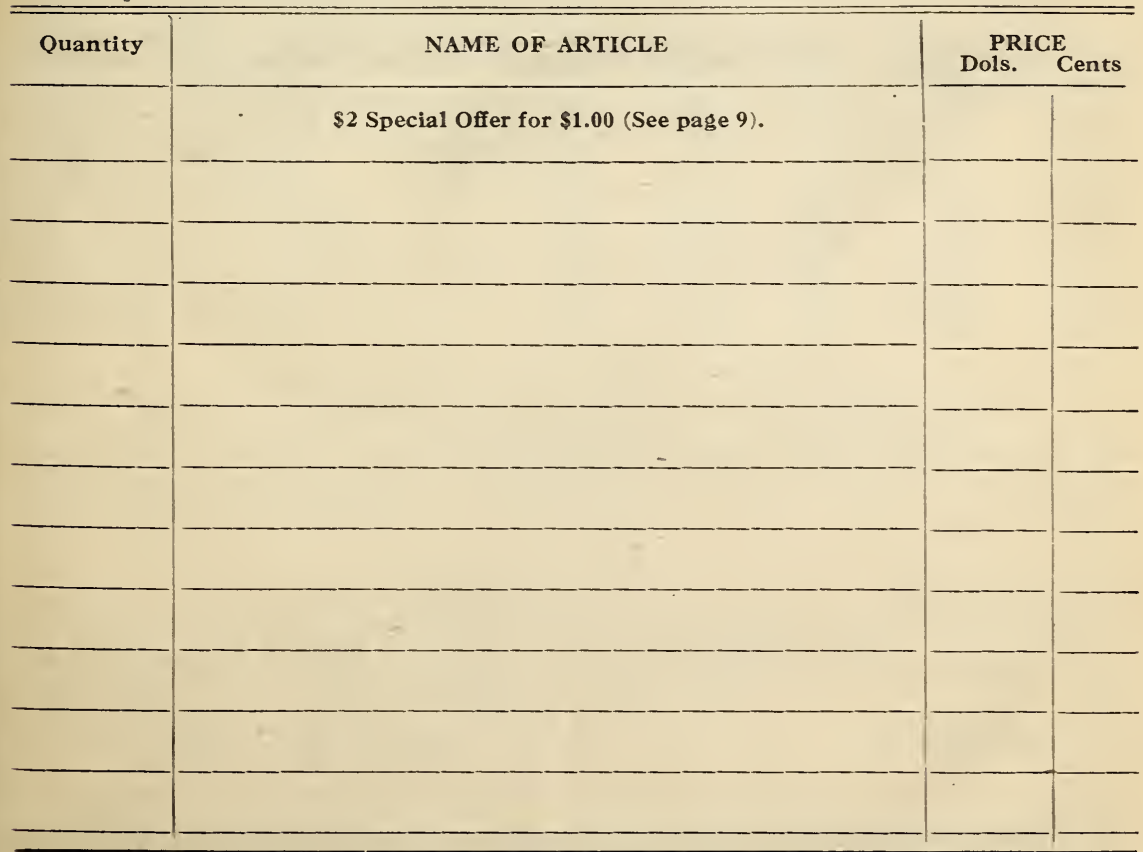




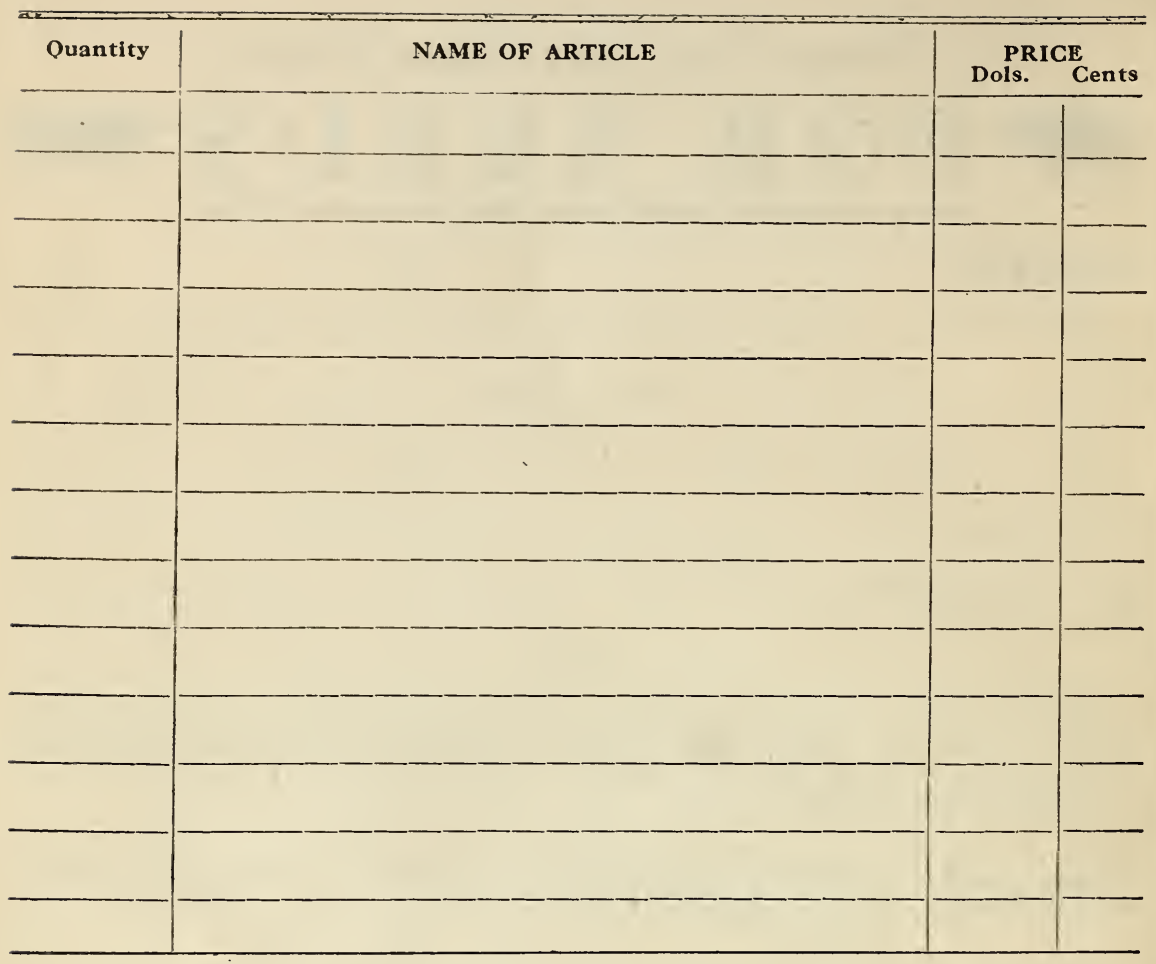

We shall consider it a special favor if you will write here the Names and Addresses of your neighbors who usually send for their seeds. Please do not write anything but names and addresses in the spaces below.

NAMES
POSTOFFICE

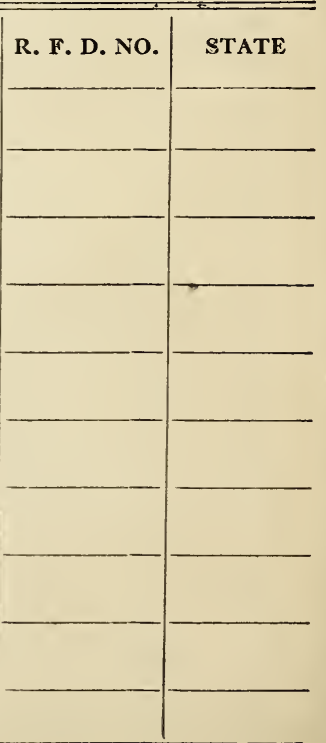




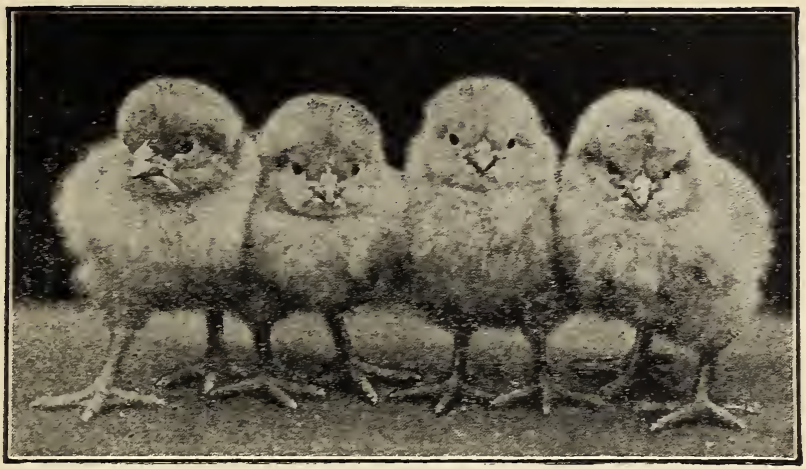

Raise Accredited Chicks and know what you're getting. We have contracted for a huge quantity of purebred Missouri Accredited Chicks and because of our big dealings are able to sell you chicks at even lower prices than they would cost from the hatchery direct. These chicks are hatched under State supervision and every bird that the eggs come from must be personally inspected and a sealed legband placed on her by an official State Inspector. Good stock means good eggs-good eggs mean good chicks-good chicks mean good poultry and good profits.

Below is a list of the varieties offered. The White Minorcas are of the genuine Booth strain. This strain is noted for its money-making hatching eggs and cockerels. White Minorcas lay a large white egg and are a pound or more heavier than leghorns in weight. The demand for these hatching eggs has always been greater than the supply.

We pay the postage and guarantee $100 \%$ live delivery. If chicks are dead, crippled or missing, have postmaster or carrier sign your statement. giving the number in such condition. This must be mailed within 24 hours or no allowance can be made.

Hatching starts February 20th; ends middle of June. Hatching every day but orders should be booked as far in advance as possible. $\$ 1.00$ per 100 chicks will book your order; balance to be sent two weeks before shipping date. REMEMBER WE SELL CHICKS ONLY-No stocks or eggs.

$$
\text { Variety Price for } 25
$$

S. C. White Leghorns............... 4.00

S. C. Brown Leghorns................... 1.00

S. C. English White Leghorns.......... 4.25

Barred Plymouth Rocks............ 4.25

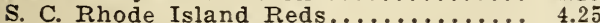

Buff Plymouth Rocks............ 4.50

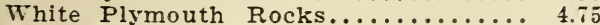

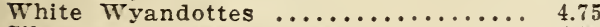

Silver Laced Wyandottes............. 4.75

Buff Orpingtons ................. 4.75

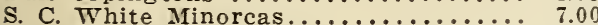

Heavy breeds assorted............. 4.00

Light breeds assorted......................... 3.75

$\begin{array}{ll}50 & 100 \\ \$ 7.00 & \$ 13.00 \\ 7.00 & 13.00 \\ 7.50 & 14.00 \\ 7.50 & 14.00 \\ 7.50 & 14.00 \\ 8.00 & 15.00 \\ 8.50 & 16.00 \\ 8.50 & 16.00 \\ 8.50 & 16.00 \\ 8.50 & 16.00 \\ 13.00 & 25.00 \\ 7.00 & 13.00 \\ 6.75 & 11.50\end{array}$

500

$\$ 63.00$

63.00

68.00

68.00

68.00

73.00

78.00

78.00

78.00

78.00

122.00

63.00

57.50
1,000 $\$ 121.00$ 121.00 134.00 134.00 134.00 114.00 154.00 154.00 154.00 154.00 230.00 124.00 115.00

The above prices are by Parcel Post Prepaid.

(NOTE: Light breeds assorted are leghorns, etc., heavy breeds are the other kinds. Selection must be left with us when ordering assorted chicks.)

Orders are booked as received. So be sure to order early. Send yours in and We'll book as close to date wanted as possible and if date doesn't suit we'll cancel. This will save unnecessary letter writing and time for you. It pays to buy Quality chicks-these are fine chicks.

May 17,1927

"I have received onion plants which you sent in place of those spoiled in transit. They were in fine shape and I thank you for your part in doing as you say you do, 'SAFE ARRIVAL GUARANTEED,

MRS. MIARIE PHARO Manston, Wis.
Feb. $15,1927$.

"This makes the fourth year that I have ordered from your company and never had a single plant to die yet. Please fill enclosed order at once." O. R. WEBB

R. 1, Box 124, Ozan, Ark. 


\section{ONE OF OUR FIELDS OF FROST PROOF CABBAGE PLANTS}

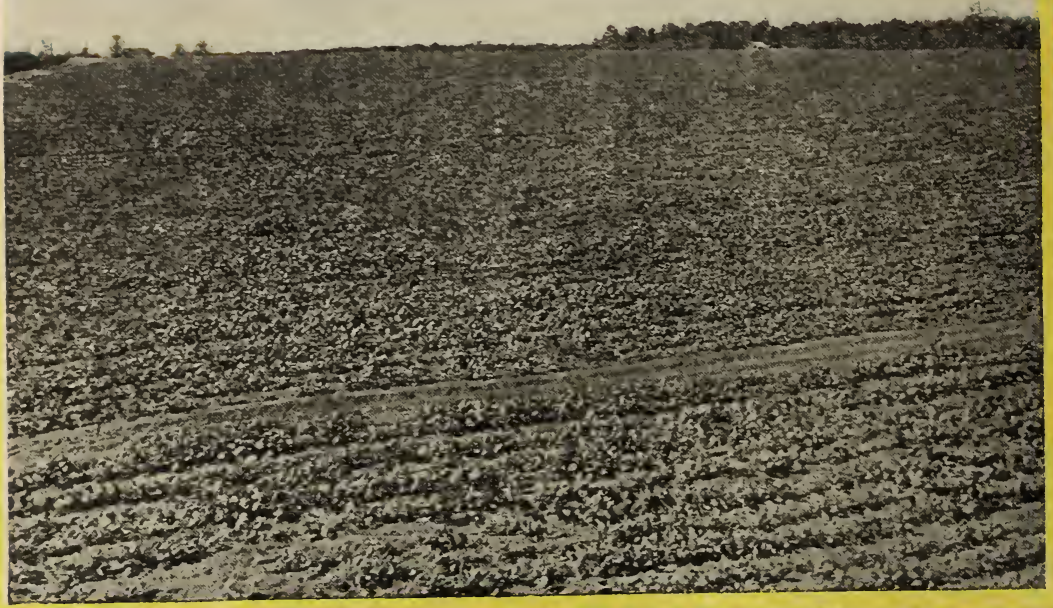

A View of Our Many Cabbage Fields. 210 acres in all devoted to cabbage plants alone. It's an Industry with us - not a backyard proposition.

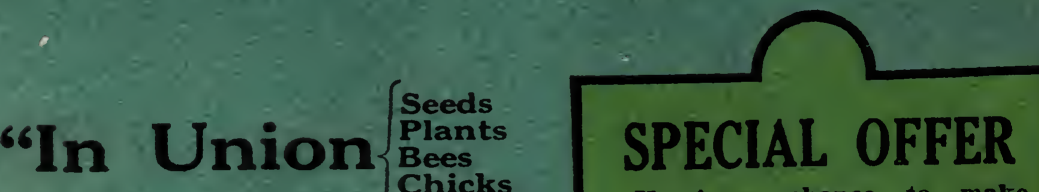

Here's a chance to make double money-money off the vlants you raise and money of those you sell. Order plants for gou $r$ neighborhood and sell them at our small quantity prices and save the difference.

\section{Onion Plants} 400 Cabbage
Plants

Well hip you these choice plants, of our own selection, or of varieties you want (excepting Prizehead Cabbage Plants) at this special price, postpaid. You'll save money by ordering this assortment. If these are more plants than you need. sell them to your neighbors at a profit.

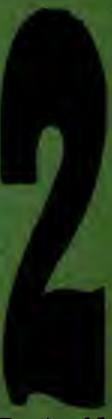

Become our agent. Order plants at express prices and sell at our parcel post prices. Write us for details. 